\title{
Review \\ A Critical Review on Decarbonizing Heating in China: Pathway Exploration for Technology with Multi-Sector Applications
}

\author{
Xiaoyang Hou ${ }^{1}$, Shuai Zhong ${ }^{2, *}$ and Jian'an Zhao ${ }^{2, *}$ \\ 1 School of Earth Sciences and Resources, China University of Geosciences (Beijing), Beijing 100083, China; \\ houxy@cugb.edu.cn \\ 2 Institute of Geographic Sciences and Natural Resources Research, Chinese Academy of Sciences, \\ Beijing 100101, China \\ * Correspondence: zhongshuai@igsnrr.ac.cn (S.Z.); zhaoja@igsnrr.ac.cn (J.Z.)
}

check for updates

Citation: Hou, X.; Zhong, S.; Zhao, J. A Critical Review on Decarbonizing Heating in China: Pathway

Exploration for Technology with Multi-Sector Applications. Energies 2022, 15, 1183. https://doi.org/ $10.3390 /$ en15031183

Academic Editor: Frede Blaabjerg

Received: 6 January 2022

Accepted: 3 February 2022

Published: 6 February 2022

Publisher's Note: MDPI stays neutral with regard to jurisdictional claims in published maps and institutional affiliations.

Copyright: (C) 2022 by the authors. Licensee MDPI, Basel, Switzerland. This article is an open access article distributed under the terms and conditions of the Creative Commons Attribution (CC BY) license (https:// creativecommons.org/licenses/by/ $4.0 /)$.

\begin{abstract}
Coal-fired heating is the main method of heating in China, causing serious air pollution and large amounts of $\mathrm{CO}_{2}$ emissions. Decarbonizing heating is important to reduce carbon emissions, and choosing a suitable heating technical scheme is conducive to the early realization of carbon neutrality in China. Coal to gas and coal to electricity transformation projects were carried out in 2017 and achieved remarkable effects. This study compares the current domestic and international clean heating modes, where gas heating, electric heating, heat hump heating, biomass heating, and solar heating coupling system are taken into account. The heating technology potential and heating support aspects, including the industrial sector, building sector, carbon capture and storage (CCS) technology, and publicity are explored as well. Regarding the actual situation in China, a comparative analysis is also conducted on the different types of heat pumps, and then an optimal heating scheme for urban and rural areas is proposed. It is suggested that the urban area with centralized heating can install ground source heat pumps, and the rural area with distributed heating can apply a coupling system of solar photovoltaics to ground source heat pumps (PV-GSHP). Based on current policies and standards support, this study calculates the carbon emissions of this scheme in 2030 and provides a detailed analysis of relevant parameters. The feasibility and superiority of the scheme are confirmed by comparison and discussion with other studies. Moreover, specific measures in planning, subsidy, construction, and electricity are proposed to implement the heating scheme. This study provides a reference for the mode selection and technical scheme of heating decarbonation in China, and that could be also considered in other regions or countries.
\end{abstract}

Keywords: decarbonizing heating; carbon emissions; heat hump; carbon emissions accounting; heating scheme

\section{Introduction}

China's rapid economic growth is accompanied by massive consumption of fossil fuels, posing a serious threat to human health and global warming. As the world's largest coal consumer and carbon emitter, China is responsible for 10\% of emissions [1]. In 2015, China agreed to the Paris Agreement and declared achieving the carbon emissions peak by 2030 and carbon neutrality by 2060 [2]. During the 13th Five-Year Plan period, building a clean energy society and protecting the ecological environment became China's national strategy [3].

Coal-fired heating is the main method of winter heating in China. According to statistical data, China consumed a total of approximately 400 million tons of coal for heating in 2016, a value that accounts for $83 \%$ of the total residential heat demand in urban and rural areas [4]. In the 1950s, the central government published the winter heating policy in which centralized heating was used in cities north of the Qinling-Huaihe Line, distributed heating was used for rural households, and no centralized heating was 
used in the south [5]. In addition, air pollution in Northern China has obvious seasonal characteristics, that are closely related to winter coal-fired heating [6]. The transition to decarbonizing heating is not only in line with national strategic requirements but also significant for China to achieve its carbon emissions peak by 2030 and carbon neutrality by 2060 .

In 2017, the National Development and Reform Commission and other governmental departments in China published the Clean Heating Plan in North China in Winter (2017-2021), identifying "coal to electricity" and "coal to gas" as the winter heating modes for " $2+26$ cities" in the North. Coal to gas and coal to electricity means replacing coal-fired heating with natural gas or electricity infrastructure, which indicates the transformation of heating energy in China [7]. By the end of 2017, nearly 4.75 million households had successfully switched their heating method from coal to gas or electricity. The Plan (2017-2021) proposed that the clean heating rate should reach 70\% in 2021 in Northern China [8]. The transition path of decarbonizing heating has not yet reached a consensus. With the emergence of renewable energy heating and the continuous development of various technologies at home and abroad, it provides options for the design of decarbonizing heating in China.

The novelty of this study has three aspects: (1) Comparing and selecting the optimal heating model from multiple perspectives based on the actual situation in China; (2) analyzing the current status, problems faced, and future prospects of changes in four major aspects related to heating in China: industry, buildings, carbon capture and storage (CCS) technology, policies, and publicity for the first time; and (3) proposing a feasible low-carbon heating technology scheme for China based on the combination of the first two analyses. The scheme is based on the current actual situation related to urban and rural heating in China as well as the latest policies. The carbon emissions of 2030 are calculated and confirmed to be superior.

Most heating studies, not just in China, are focused on one or two perspectives related to clean heating itself. Few studies have combined comparative studies of clean heating modes with their related support and technology aspects. Studies of coal to gas and coal to electricity transformation projects are focused on the comparison of the two [9-13], environmental benefits [14,15], economic benefits [16,17], and practical investigation studies $[18,19]$. In addition, domestic and international heating studies commonly include clean heating modes [20,21], comparative studies based on environmental or economic indicators [5,22-25], heating structure studies based on temperature growth limited to $2{ }^{\circ} \mathrm{C}$ or $1.5^{\circ} \mathrm{C}[6,26]$, and district heating potential $[27,28]$. In addition, few studies have proposed specific action measures based on the actual situation of heating. The study fills the above gap.

This study aims to address the national need regarding how China can achieve heating decarbonization concerning a feasible technical system applied in different sectors. The optimal path will be explored to propose a more specific scheme for reaching the sustainable utilization of heating energy, especially in urban and rural areas.

\section{Progress of Decarbonizing Heating in China}

This section provides an analysis and summary of the progress of coal to gas and coal to electricity projects in China. Coal to gas means changing the method of heating by burning coal to burning natural gas, mainly through boilers, cogeneration (CHP), and wall-mounted natural gas heaters [29]. By the end of the heating season in 2019, the area heated by natural gas reached $3.06 \times 10^{9} \mathrm{~m}^{2}$ and the clean heating area increased by $31 \%$ compared to 2016. Coal to electricity means heating with electrical energy, mainly through electric boilers, electric heaters, and heat pumps. By the end of 2017, the area heated by electrical energy in the northern region had reached $1.03 \times 10^{9} \mathrm{~m}^{2}$ [22]. In the southern region, the winter time is short and the clean heating modes are mainly through heat pumps and wall-mounted natural gas heaters [30,31]. 


\subsection{Comparison of Coal to Electricity and Coal to Gas}

Three major indicators were used to analyze the progress of clean heating transformation in China (Table 1).

For energy efficiency, heating using electricity, especially heat pumps, has the highest efficiency [32,33]. For heating energy consumption, both natural gas and coal-fired heating have higher energy consumption than electricity. The energy consumption of heat pumps is $1 / 3$ of direct electric heating [34]. In conclusion, heat pump heating is the optimal choice for energy efficiency and energy consumption.

For economic effects, the clean heating transformation in China costs tens of billions of RMB per year. The cost of clean heating was up to 43.1 billion RMB, of which government expenditure accounted for 44\% and residents' expenditure accounted for 56\% in 2017 [23]. Residents are more likely to face heating poverty under coal-to-electricity and coal-togas heating modes [23,35]. As shown in Table 1, heating with electricity, especially heat pumps, is the most effective clean heating method in comparison with other economic indicators [34,36-38], although the initial investment in rural areas is the highest.

For environmental effects, with the advancement of the clean heating transformation, all air pollution indicators in pilot cities decreased strongly in December 2017 and the highest reduction in $\mathrm{CO}_{2}$ content reached more than 50\% [39]. As shown in Table 1, heating using electricity is the most efficient method for $\mathrm{CO}_{2}$ reduction. Compared with other gas indicators, some studies show lower pollutant emissions of natural gas heating and some studies show even lower pollutant emissions for heat pump heating [36,37]. The reason for the different results may be related to the electric power structure of heating using electricity. The increase in emissions of nitrogen oxides $\left(\mathrm{NO}_{X}=\mathrm{NO}+\mathrm{NO}_{2}\right)$ in the air can alter the atmospheric oxidation process and directly affect human health. It is controversial whether natural gas heating increases $\mathrm{NO}_{X}$ emissions. Some studies suggest that it is strongly associated with increased $\mathrm{NO}_{X}$ emissions $[15,40]$, and some suggest other factors, such as vehicles, increase emissions [14]. Environmental effects are closely related to health impacts. According to statistics, the national clean heating transition brought approximately 109.85 billion RMB in health benefits during the heating period in $2017[23,41]$.

Table 1. Comparison of indicators of heating transformation in China.

\begin{tabular}{|c|c|c|c|c|c|}
\hline \multirow{2}{*}{\multicolumn{2}{|c|}{ Heating Modes (Year) }} & \multirow{3}{*}{$\begin{array}{l}\text { Coal } \\
75 \%\end{array}$} & \multirow{3}{*}{$\begin{array}{c}\text { Natural Gas } \\
85 \%\end{array}$} & \multicolumn{2}{|c|}{ Electricity } \\
\hline & & & & \multirow{2}{*}{$\begin{array}{c}\begin{array}{c}\text { Heat Pump } \\
\text { (ASHP) }\end{array} \\
2\end{array}$} & \multirow{2}{*}{$\begin{array}{c}\text { Direct Electric } \\
\text { Heating }\end{array}$} \\
\hline \multirow{2}{*}{$\begin{array}{l}\text { Energy efficiency and } \\
\text { energy consumption }\end{array}$} & Energy efficiency ratio [32] (2021) & & & & \\
\hline & Energy consumption ratio [33] (2019) & 4 & 3.5 & \multicolumn{2}{|c|}{1} \\
\hline \multirow{4}{*}{ Economic effect } & $\begin{array}{l}\text { The price of unit calorific } \\
\text { value [33] (2019) }\end{array}$ & 1 & 2.27 & 1.5 & 3 \\
\hline & $\begin{array}{l}\text { Initial investment of rural heating in the } \\
\text { North (RMB/household) [37] (2020) }\end{array}$ & - & 8000 & $14,000-18,000$ & $12,000-13,000$ \\
\hline & $\begin{array}{c}\text { The ratio of average heating cost of } 2+26 \\
\text { cities [42] (2019) }\end{array}$ & 6.28 & 12.7 & \multicolumn{2}{|c|}{11.9} \\
\hline & $\begin{array}{c}\text { Average cost of heating } \\
\text { (RMB/household) [23] (2021) }\end{array}$ & 1600 & 4000 & \multicolumn{2}{|c|}{3600} \\
\hline \multirow{4}{*}{$\begin{array}{l}\text { Environmental Effect } \\
\text { [11] (2019) }\end{array}$} & $\mathrm{CO}_{2}\left(\mathrm{~g} / \mathrm{MJ}_{\text {net }}\right)$ & 350.21 & 160.42 & \multicolumn{2}{|c|}{34.8} \\
\hline & $\mathrm{CO}\left(\mathrm{g} / \mathrm{MJ}_{\mathrm{net}}\right)$ & 6.33 & 0.04 & \multicolumn{2}{|c|}{0.42} \\
\hline & $\mathrm{PM}_{2.5}\left(\mathrm{mg} / \mathrm{MJ}_{\mathrm{net}}\right)$ & 105.7 & 0.12 & \multicolumn{2}{|c|}{5.48} \\
\hline & $\mathrm{SO}_{2}(\mathrm{~g} / \mathrm{MJ} \mathrm{Jnet})$ & 13.33 & 0 & \multicolumn{2}{|c|}{0.03} \\
\hline
\end{tabular}




\subsection{Evaluation of Coal to Electricity and Coal to Gas}

Natural gas heating is not suitable for large areas in China and is widely regarded as a kind of transitional resource from coal to renewable energy [20]. Natural gas is concentrated in central and western China and it is difficult and costly to extract. The heating demand is mostly concentrated in the eastern regions. West-east gas transmission increases the cost of gas transportation. The advancement of the coal-to-gas project has caused a massive shortage of natural gas and the former Ministry of Environmental Protection had to allow cities that had not completed the construction of natural gas infrastructure to continue burning coal for heating. Importing is the main method of natural gas supply in China. However, the external dependence of Chinese natural gas reached more than $45 \%$ in 2019 [32], which threatens the security of Chinese energy supply. There are outstanding problems in China's natural gas distribution and management system. In addition, China lacks the experience and technology to build large and complex pipe networks [18]. The transformation of coal to electricity for heating has raised the demand for electricity from coal-fired power plants. According to statistics, the maximum daily electricity consumption in China increased by more than 15\% in January 2018 [12], aggravating the carbon emissions contradiction between heating and electricity production. Coal to electricity has a higher potential than coal to gas. Cleanliness of electrical energy will lead heating to a further reduction in emissions.

\section{Technical Potential and Evaluation}

This section will discuss the changes in the development of heating resource utilization and heating support aspects. On the one hand, it compares domestic and foreign clean heating resource utilization from multiple perspectives. On the other hand, it discusses the changes in heating support aspects, such as the industrial sector, building sector, CCS technology, and policies and publicity. Finally, a heating scheme was set by combining the above two aspects.

\subsection{Clean Heating Resource Utilization Cases and Technology Evaluation}

\subsubsection{Cases of Heating Technology Applications in Developed Countries}

Studying clean heating in developed countries or regions at home and abroad and analyzing the existing clean heating modes can help to reasonably choose the heating mode in China. There is a summary of the clean heating modes emerging in developed countries or regions in the past five years (Table 2), which shows that the utilization of heating resources, mainly focuses on shallow geothermal (the utilization of heat pumps), solar energy, natural gas, biomass energy, and power to gas (P2G).

Table 2. Summary of clean heating literature in the last five years.

\begin{tabular}{|c|c|c|}
\hline Author/Year/Reference & Application Area & Technology Evaluation \\
\hline Buker et al./2016/[43] & - & An overview of the heating system coupling solar to heat pumps \\
\hline Lund et al./2016/[21] & Denmark & $\begin{array}{l}\text { Feasibility of heat pumps for centralized heating using ambient heat } \\
\text { sources }\end{array}$ \\
\hline Nastasi et al./2017/[44] & Rome, Berlin, Copenhagen & $\begin{array}{l}\text { The analysis of application scenario and future outlook for power to } \\
\qquad \text { gas (P2G) heating }\end{array}$ \\
\hline Ashfaq et al./2018/[5] & Aarhus, Denmark & $\begin{array}{l}\text { The technical and economic feasibility of coupling the heating network } \\
\text { with the grid for heat pumps heating and the correlation between the } \\
\text { operating cost of heat pumps heating and low carbon electricity }\end{array}$ \\
\hline Gluyas et al./2018/[45] & UK & $\begin{array}{c}\text { Feasibility of large-scale development of geothermal resources for } \\
\text { heating }\end{array}$ \\
\hline
\end{tabular}


Table 2. Cont.

\begin{tabular}{|c|c|c|}
\hline Author/Year/Reference & Application Area & Technology Evaluation \\
\hline Popovski et al./2018/[25] & $\begin{array}{l}\text { Matosinhos, } \\
\text { Portugal }\end{array}$ & $\begin{array}{c}\text { The demonstration of the superiority of the system coupling } \\
\text { photovoltaics and heat pumps from a socioeconomic and individual } \\
\text { economic point of view, and the sensitivity analysis of heating } \\
\text { influence factors }\end{array}$ \\
\hline Sheikh et al./2019/[20] & $\begin{array}{l}\text { California, } \\
\text { USA }\end{array}$ & $\begin{array}{l}\text { Comparing the feasibility of electrification, solar energy, biomass } \\
\text { energy, and power to gas heating in California }\end{array}$ \\
\hline Pelda et al./2020/[46] & Germany & $\begin{array}{l}\text { The feasibility of coupling industrial waste heat sources to solar } \\
\text { thermal power into central heating systems in Germany's Climate } \\
\text { Action Plan } 2050\end{array}$ \\
\hline Vaishnav et al./2020/[13] & America & $\begin{array}{l}\text { Heating modes shift from gas to heat pumps with peak electricity } \\
\text { demand in winter }\end{array}$ \\
\hline Fajardy et al./2021/[26] & - & $\begin{array}{c}\text { The technical and economic feasibility of biomass heating making a } \\
\text { significant contribution to emissions reductions under the global } \\
\text { warming targets of } 1.5^{\circ} \mathrm{C} \text { and } 2{ }^{\circ} \mathrm{C} \text { through the use of carbon capture } \\
\text { and storage (CCS) technology }\end{array}$ \\
\hline Gaur et al./2021/[47] & - & $\begin{array}{l}\text { The determinants of heat pumps application in } \\
\text { decarbonizing heating and the impediments to centralized heating }\end{array}$ \\
\hline Tissen et al./2021/[48] & $\begin{array}{l}\text { Vienna, } \\
\text { Austria }\end{array}$ & $\begin{array}{l}\text { Exploring the feasibility of developing shallow } \\
\text { geothermal resources for heating in Vienna and how to use geothermal } \\
\text { resources heating }\end{array}$ \\
\hline Slorach et al./2021/[24] & England & $\begin{array}{l}\text { Analyzing heating modes such as gas, heat pumps, and electric heating } \\
\text { on the basis of the Life Cycle Assessment and analyzing the impact on } \\
\text { the environment }\end{array}$ \\
\hline Su et al./2021/[28] & $\begin{array}{l}\text { Stockholm, } \\
\text { Sweden }\end{array}$ & $\begin{array}{l}\text { Potential heat source distribution for zero-carbon central heating in } \\
\text { Stockholm in } 2040\end{array}$ \\
\hline
\end{tabular}

\subsubsection{Electrification of Heating}

Electrification of heating includes electrical resistance heating and various types of heat pump heating (Table 3). The potential decarbonization capacity can reach $100 \%$. Heat pump heating is the optimal method of electrification of heating, with a heating efficiency of $2-5$, a low average marginal cost of decarbonization, and a wide range of applications. The pollutant emissions of heat pumps are lower than those of direct electric heating. Heat pumps can be divided into an air source heat pump (ASHP) and a ground source heat pump (GSHP) based on different heat sources. Different types of heat pumps have different application conditions and environments [49,50]. At present, the heating area of GSHP in Northern China has exceeded $1.5 \times 10^{8} \mathrm{~m}^{2}$ and there is a certain scale of use in southern regions such as Jiangsu, Hubei, and Shanghai.

\subsubsection{Biomass Heating}

Biomass heating means using renewable biomass resources for heating. Most rural areas in China are rich in biomass resources, especially in North and Northeast China. At present, most rural areas in China are heated directly with wood or straw and pollutant emissions are usually 4 to 10 times higher than those of coal-fired boilers [51]. Fully transforming and using biomass resources in rural areas is conducive to improving the quality of heating in rural areas. The common biomass heating modes are boiler heating, $\mathrm{CHP}$ heating, and biogas heating. The highest utilization efficiency and heating efficiency of biomass are achieved through power generation. The real decarbonization of heating needs to use CCS technology. Currently, the UK [52,53], Finland [54], and other countries use it as the most important renewable resource. By the end of 2019, the heating area of biomass CHP in China exceeded $3.4 \times 10^{8} \mathrm{~m}^{2}$ and the heating area of biomass boilers exceeded $9 \times 10^{7} \mathrm{~m}^{2}[55]$. 


\subsubsection{Solar Heating Coupling System}

Coupling systems for solar resources and heat pumps are widely utilized, which include the coupling system of solar thermal to heat pumps, the coupling system of photovoltaic to heat pumps (PV-HP), and the coupling system of photovoltaic/thermal to heat pumps (PV/T-HP). The coupling system of solar thermal to heat pumps can effectively reduce emissions and has a certain energy-saving effect. However, it is less obvious in improving heating efficiency, which can solve the problem of disruption of the cold and heat balance of soils. The high initial investment is an important factor limiting the application of this coupling system [56,57]. The coupling system of PV-HP can significantly improve heating efficiency, providing a heating option for areas lacking electricity. PV/T-HP is a new heating mode in which the power generation and heating efficiency are higher. However, the current application is still immature. A team from the Delft University of Technology in the Netherlands verified its efficiency in power generation and heating. There are also test applications in Qinghai, China [58].

The utilization potential of solar energy resources in China is huge. Solar energy resources are abundant in China, especially in the Qinghai-Tibet Plateau. The annual average sunshine in the cold and severe cold regions of China is above $3000 \mathrm{~h}$ and the total radiation is above $5800 \mathrm{MJ} / \mathrm{m}^{2}$ [59]. By the end of 2021, it was estimated that the area of buildings heated by solar energy in China will reach $5 \times 10^{7} \mathrm{~m}^{2}$ [22]. The utilization of solar energy resources is related to the duration and intensity of sunlight, and the installation of energy storage systems such as soil burial pipes and phase change materials can further increase their efficiency [60]. The efficiency of solar thermal conversion is not as high as that of PV generation.

\subsubsection{Summary of Clean Heating}

By comparing clean heating modes (Table 3), there are three findings:

1. Different regions in Northern China have different advantages of renewable resources, such as solar energy resources in the western region and biomass energy resources in Northern and Northeastern China.

2. Renewable resources (biomass energy and solar energy) can maximize the heating efficiency through the utilization of power generation or CHP.

3. The use of heat pumps is the optimal low-carbon heating path in China. The use of solar energy resources coupled with heat pump systems can further improve heating efficiency. The low-carbon heating of biomass must be combined with CCS technology.

In addition, synthetic methane heating produced by electricity, namely, "power to gas $(\mathrm{P} 2 \mathrm{G})$ ", can effectively supplement natural gas resources. However, the current efficiency of electrolysis water to produce hydrogen is $50-70 \%$, while the efficiency of methane preparation of hydrogen is low [61]. The process of synthesis requires large amounts of electricity in order to be supported. Compared with several other heating modes, the heating efficiency of P2G is low, the marginal decarbonization cost is high, and the decarbonization capacity is poor. It is not used as an option for heating. 
Table 3. Evaluation of common clean heating modes.

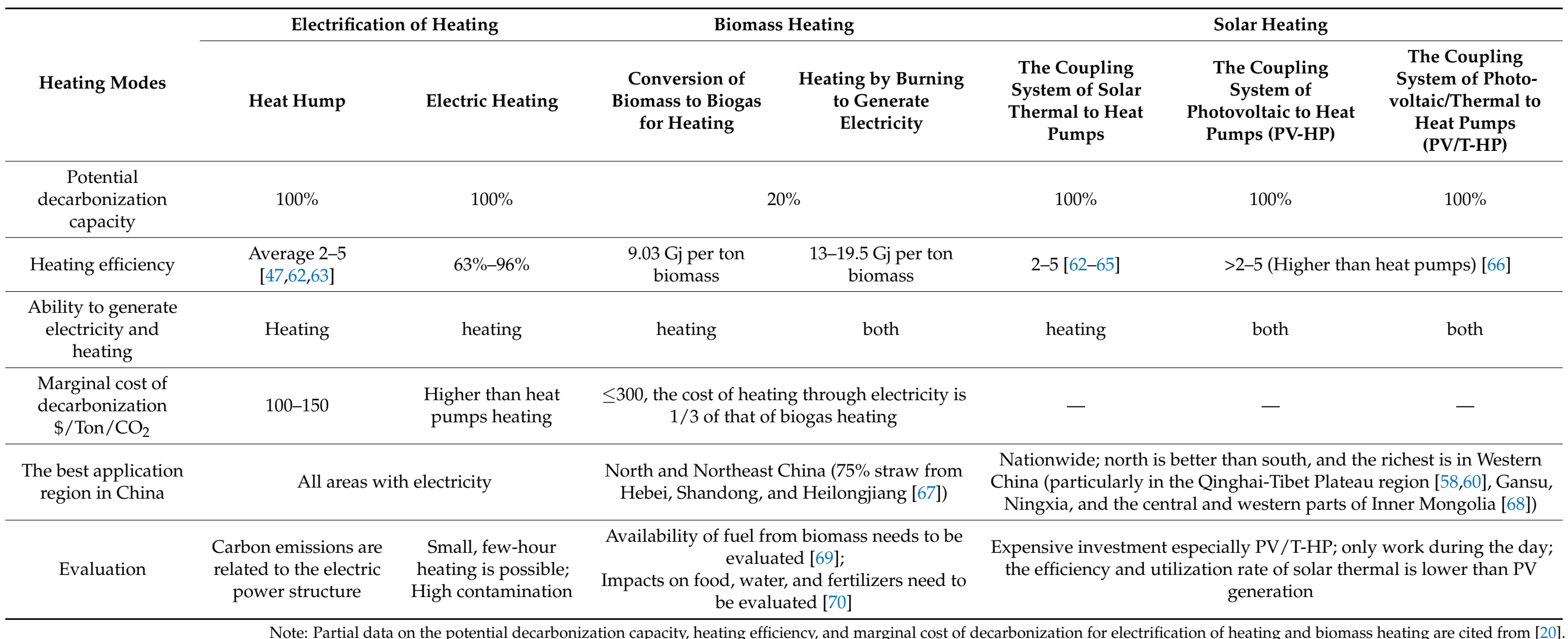

Note: Partial data on the potential decarbonization capacity, heating efficiency, and marginal cost of decarbonization for electrification of heating and biomass heating are cited from [20]. 


\subsection{Application Sectors of Heating Technology and Its Decarbonization Program}

There are four aspects of heating technology application and decarbonization concerns: industrial sector, building sector, CCS technology, and publicity. Understanding the development and changes in four aspects at home and abroad has indicative significance for Chinese decarbonizing heating. The development of these four aspects in the last five years at home and abroad is shown in Table 4 . The industrial sector is mostly focused on the utilization of clean energy, CHP, and industrial waste heat. The building sector contains aspects such as building energy-saving materials, energy-saving design and technology, and selection of heating methods. CCS technologies contain aspects such as the current development status, the application and research in thermal power plants, industrial utilization of different CCS technologies, and policy-related feasibility and drawbacks.

Table 4. The development of heating supports at home and abroad in the last five years.

\begin{tabular}{|c|c|c|}
\hline Field & Author/Year/Reference & Main Content \\
\hline \multirow[t]{3}{*}{ Industry } & Leurent, et al./2017/[54] & Major obstacles to the implementation of nuclear cogeneration $(\mathrm{CHP})$ for heating \\
\hline & $\begin{array}{l}\text { Kosmadakis } \\
\text { et al./2019/[71] }\end{array}$ & Potential recycling of industrial waste heat utilization \\
\hline & Thiel et al./2021/[72] & Four ways to achieve zero-carbon industrial heating \\
\hline \multirow[t]{7}{*}{ Building } & Shi et al./2016/[73] & $\begin{array}{c}\text { Technology advancement and renewable energy utilization on carbon reduction in } \\
\text { buildings }\end{array}$ \\
\hline & Amoruso et al./2018/[74] & Building energy efficiency policies and technology solutions \\
\hline & Leibowicz et al./2018/[75] & A multifaceted argument for a decarbonizing heating strategy of buildings \\
\hline & Broad et al./2020/[76] & $\begin{array}{l}\text { Technical solutions for the transformation of building heating resources from gas to } \\
\text { electricity }\end{array}$ \\
\hline & Hamburg et al./2020/[77] & Building design for zero energy consumption and building thermal performance \\
\hline & Uidhir et al./2020/[78] & Energy-saving benefits of different renovations of building houses \\
\hline & $\begin{array}{l}\text { Zabnienska } \\
\text { et al./2021/[79] }\end{array}$ & The extent of reduction of energy consumption in PV/T system of home heating \\
\hline \multirow[t]{5}{*}{ CCS } & Bui et al./2018/[80] & $\begin{array}{c}\text { An overview of the current advances in carbon capture and storage (CCS) technology } \\
\text { and the challenges of applying CCS technology in the UK }\end{array}$ \\
\hline & Sifat et al./2019/[81] & $\begin{array}{l}\text { An overview of the current status of the utilization of CCS technology in thermal } \\
\text { power plants, with suggestions for system improvements }\end{array}$ \\
\hline & $\begin{array}{l}\text { Muhammad } \\
\text { et al./2020/[82] }\end{array}$ & A new CCS process configuration that minimizes energy consumption \\
\hline & Brandl et al./2021/[83] & The relationship between carbon capture rate and economic cost of CCS technology \\
\hline & Xing et al./2021/[84] & $\begin{array}{l}\text { Low-carbon development deployment of biomass and coal-fired power plants } \\
\text { co-firing in China }\end{array}$ \\
\hline \multirow[t]{8}{*}{$\begin{array}{l}\text { Policy and } \\
\text { Advocacy }\end{array}$} & Buchele et al./2018/[85] & $\begin{array}{l}\text { Feasibility of implementation of different heating policies under different conditions } \\
\text { in Brasov, Romania }\end{array}$ \\
\hline & Knobloch et al./2019/[86] & Impact of household behavior on policies to decarbonation in 2050 \\
\hline & Narula et al./2019/[87] & $\begin{array}{l}\text { Three key strategies for low-carbon heating in Switzerland: reducing the heating } \\
\text { demand of buildings, centralized heating, and heating by heat pumps }\end{array}$ \\
\hline & Schwarz et al./2019/[88] & $\begin{array}{c}\text { Impact of the type of policies on the implementation of heating technologies, with } \\
\text { Switzerland as an example }\end{array}$ \\
\hline & Frank et al./2020/[53] & Analysis of the low carbon heating policies in the UK and Germany \\
\hline & Feng et al./2021/[23] & $\begin{array}{l}\text { The estimation of economic costs and health benefits of heating in China and } \\
\text { recommendations for clean heating transformation }\end{array}$ \\
\hline & Herbes et al./2021/[89] & $\begin{array}{c}\text { Problems and solutions in biomass heating policies in the UK, Germany, Austria, and } \\
\text { Switzerland }\end{array}$ \\
\hline & Sovacool et al./2021/[90] & $\begin{array}{c}\text { Willingness and preference for decarbonizing heating in households in five European } \\
\text { countries }\end{array}$ \\
\hline
\end{tabular}




\subsubsection{Industrial Sector}

Energy from industrial production is the main source of heating in China and cleaner industrial production is conducive to low-carbon heating. China is rich in coal resources. At the end of 2016, the proportion of coal-fired and gas-fired heating in northern cities was $77 \%$ and $18 \%$, respectively. With the transformation of clean heating, the proportion of these two reached by $72 \%$ and $20 \%$ by the end of 2018 , respectively, while the proportion of electrification of heating, renewable energy heating, and industrial waste heat supply was $4 \%, 3 \%$, and $1 \%$, respectively. This indicates that the current status of coal-fired heating in China is being replaced by diversified clean heating modes [91-93].

Centralized heating, the CHP of clean energy, and industrial waste heat are the development directions of industrial heating. Centralized heating, which can reduce building heating energy consumption by approximately $60 \%$ and heating cost by $15 \%$, is more efficient than distributed heating [94,95]. By the end of 2020, the centralized heating area in China was 12.27 billion square meters. As shown in Figure 1, the growth rate of the centralized heating area in China's counties was much faster than that in cities before 2015 . The growth rate of the centralized heating area in China's cities and counties tended to be the same after 2015. Since 2012, the ratio of the urban centralized heating area to county heating area in China has been stable at 5-6 times. CHP of coal fire is the main method of centralized heating in China, which has a low heating cost and high pollution. There is also a mismatch between the total supply and demand of thermoelectric power, as well as in time and space. CHP of clean energy is the development direction of heating. Currently, there are biomass CHP and nuclear CHP at home and abroad. Many countries in Asia and Europe use nuclear CHP for heating and its heating efficiency can reach 66\% [54]. Nuclear CHP in China is at an initial stage and the first nuclear energy source was used for heating in Haiyang City, Shandong Province, in 2021. Low-grade waste heat from industrial plants can also be used for heating. According to statistics, the highest utilization rate of industrial waste heat in Hebei Province has a heat recovery rate of only 23\% [96]. The thermal power, iron and steel, and building material industries have abundant medium-low grade waste heat resources. Industrial parks are the concentration areas of waste heat that can maximize resources [97]. The large-scale application of industrial waste heat faces three problems:

1. Industrial production is generally far from the urban population center, so the utilization of waste heat requires high costs of insulation and transportation [98].

2. Waste heat supply is subject to industrial production and operation, for example, cement plants are closed due to reduced demand in the construction industry during the winter $[97,99]$.

3. The utilization of industrial waste heat requires the use of absorption heat pumps, which have an average coefficient of performance (COP) of only 1.8 and have problems with leakage and heat transfer $[47,100]$.

\subsubsection{Building Sector}

The energy efficiency of the building sector improves heating efficiency and reduces the use of heating fuels. Currently, existing buildings in Northern Chinese cities and towns are built to a 50\% energy-efficient standard based on 1980-1981 energy consumption and new buildings are built to achieve a $65 \%$ energy-efficient standard. Energy-efficient buildings in Chinese cities accounted for more than $50 \%$, while only $20 \%$ of rural residential areas have adopted energy-efficient measures, which results in rural heating energy consumption being 2-3 times higher than that of energy-efficient buildings [51]. Chinese energy-efficient building projects started late, with current investment in this field being small and energysaving technologies underdeveloped. By the end of 2018, $1.57 \times 10^{8} \mathrm{~m}^{2}$ of energy-saving residential buildings had been renovated in Northern China [101]. The energy-saving buildings of heating mainly contain passive energy-saving aspects (energy-saving materials and energy-saving standards of buildings) and active energy-saving aspects (selection of heating modes and energy-saving technologies of building). The heating modes discussed in the previous section will not be discussed in this section. 


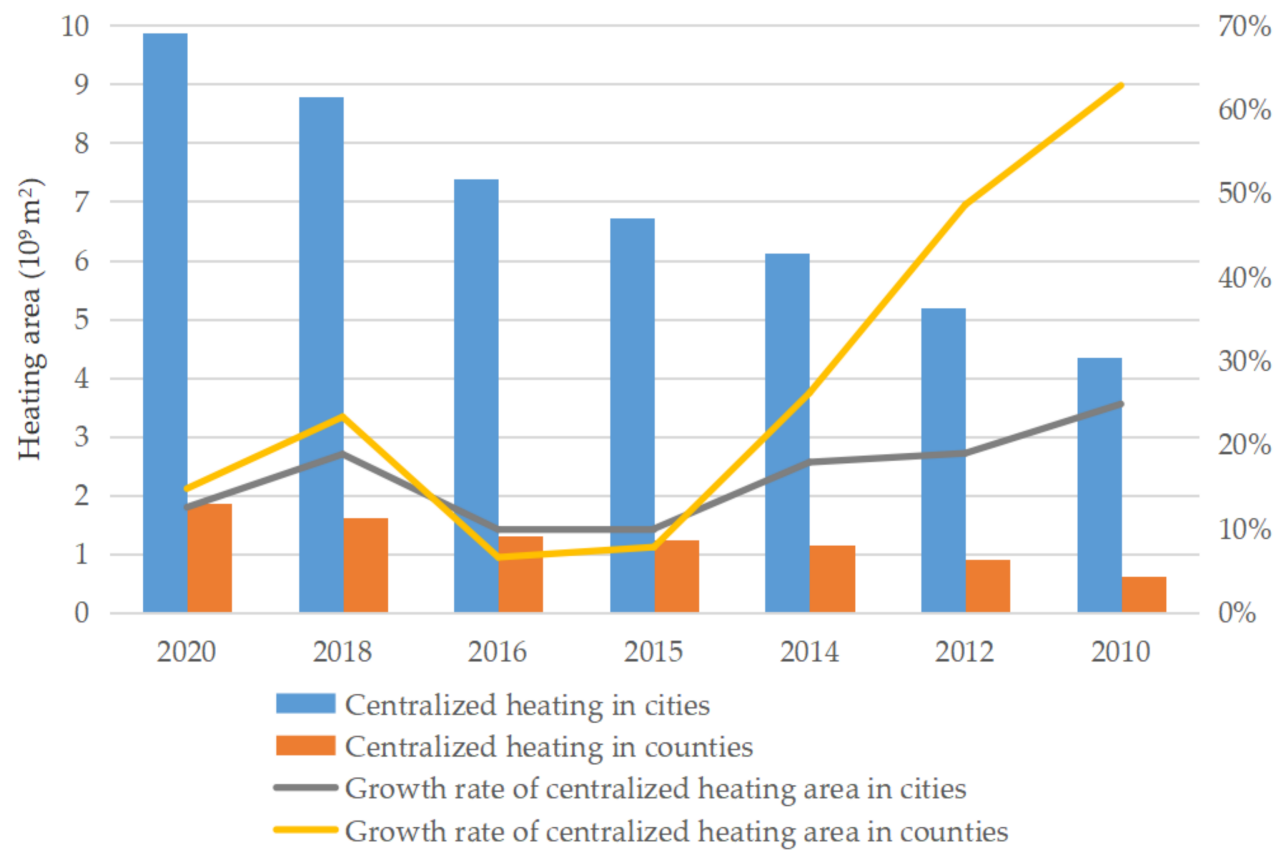

Figure 1. Change in heating area in Chinese cities and counties. (Data from China Urban and Rural Construction Statistical Yearbook 2020.)

Energy-saving materials are one of the main factors affecting the energy consumption of building heating. According to the simulation of building energy consumption, energy consumption for buildings can be reduced by $9.8 \%$ when using thermal insulation materials in severe cold regions in winter. The reasons for high energy consumption in Chinese buildings are mainly due to the backward structure of the building envelope [102,103]. A total of $20 \%$ to $50 \%$ of the utilization of building energy is consumed by the exterior heat transfer structure. Improving building exterior insulation materials is the least expensive, has the simplest operation, and is the fastest way to improve heating efficiency $[8,102,104]$. The common organic energy-saving materials in China are phenolic resin foam materials and polystyrene foam insulation boards.

Building energy efficiency standards, green buildings, and zero-energy buildings are important standards for improving energy efficiency in building heating. For energy efficiency standards of buildings, the existing standards in China are mainly set according to different geographical environments. In 2019 and 2021, the Ministry of Housing and Urban-Rural Development issued the Design Standard for Energy Efficiency of Residential Buildings in Severe Cold and Cold Zones and General Specification for Energy Conservation and Renewable Energy Use in Buildings (GB55015-2021). The latter indicates that the level of energy consumption in buildings will be further reduced by $20-30 \%$ and the energy efficiency of northern heating buildings will be increased to $75 \%$. Green buildings are the application of new energy-efficient building materials. Green buildings have become an emerging industry in recent years [105]. The Ministry of Housing and Urban-Rural Development issued Guidance on Promoting Green Building Material Product Standards, Certification and Labeling, Standard for Green Building Evaluation (GB/T50378-2019), and Uniform Standards for Civil Building Design (GB50352-2019) to promote the development of green buildings in 2017 [103,106]. Zero-energy buildings contribute to low-carbon emissions, and many countries in Asia and Europe have issued related policies [77,107]. China issued the Technical Standard for Near-Zero Energy Buildings (GB/T51350-2019) in 2019.

Energy-saving technologies in buildings can further improve the energy efficiency of heating. The frequency conversion technology is widely used in heating, which can adjust the voltage frequency according to the external temperature, reducing energy consumption $[108,109]$. The power saving rate of distributed frequency conversion technology is 
70 80\% [110,111]. Artificial intelligence technology can achieve more energy savings and artificial intelligence heat network control systems have been included in the 14th Five-Year Plan of many provinces.

\subsubsection{Application of CCS Technology in Heating}

CCS is the technology separating and capturing $\mathrm{CO}_{2}$ from emission sources and then sequestering it in a location isolated from the atmosphere. It can be widely applied to coal-fired industries in China to promote low-carbon heating. In 2019, the proportion of coal-fired power generation in China was 62.1\%, which is higher than the world average of 36.4\% [32]. The China Carbon Neutrality Framework Roadmap Study of the Chinese Academy of Sciences indicates that the primary energy consumption of coal will be $45 \%$ by 2030. Therefore, the combined application of CCS technology and coal-fired industries is of great significance for low-carbon heating in China. China has issued policies related to CCS technology since 2006, and currently 12 CCS projects are operating [112]. CCS technology can capture more than $90 \%$ of the carbon volume in coal-fired power generation. The underground storage strata in China can store $\mathrm{CO}_{2}$ for 600 years [5], and more than $80 \%$ of large carbon sources exist within $80 \mathrm{~km}$ of the storage strata, most of which are located in northern regions [113]. Most of the thermal power plants in China are located in the northern, northeastern, and eastern coastal regions of China, among which the Songliao Basin, Bohai Bay Basin, and Ordos Basin can sequester the carbon emissions of these regions. The Tarim and Junggar basins in Northwest China have great potential for sequestration. However, the current distribution of carbon sources is relatively small [114].

The CCS technologies used in coal combustion include integrated gasification combined cycle (IGCC) technology, bioenergy with carbon capture and storage (BECCS) technology, and direct air capture (DAC) technology (Table 5).

The decarbonization process of IGCC technology, which gasifies coal before combustion and then purifies it into clean fuel, consumes less energy and is less costly per unit than post-combustion carbon capture [115]. The marginal cost of decarbonization with IGCC technology is $\$ 44$ per ton $\mathrm{CO}_{2}$ (Table 5), and its power generation efficiency can reach over $40 \%$, which is higher than that of coal-fired power plants [116]. The technology is still in its infancy in China. Taking the Huaneng IGCC power plant as an example, its potential investment in coal power generation is 13,000-14,000 RMB per $\mathrm{kWh}$, far more than $8000 \mathrm{RMB}$ abroad, and it still needs a large subsidy to operate. Some researchers advocate the combined application of IGCC technology and the post combustion decarbonization of coal, which is not mature and will further increase the cost of power generation.

BECCS technology means capturing and transporting $\mathrm{CO}_{2}$ to geological storage areas during biomass combustion, which can be used in coal-fired power plants at a lower cost. BECCS technology is currently less commonly used in countries, and one of the keys is the spatial matching among biomass production areas, power plant sites, and geological storage sites. Biomass resources are abundant in North and Northeast China, where the application of BECCS technology is most feasible [67]. The marginal cost of decarbonization in a coal-fired plant with $90 \%$ biomass co-firing is $\$ 68$ per ton $\mathrm{CO}_{2}$.

The marginal cost of decarbonization of DAC technology is $\$ 88-232$ per ton $\mathrm{CO}_{2}$, and its flexibility makes it advantageous for use in the transportation industry [117]. Currently, the Clime-Works negative emission plant in Switzerland, the Carbon Engineering company in Canada, and the Global Thermostat company in the United States are all related to DAC technology. However, the overall research is in the basic stage, and it is expected to be applied to the industry in approximately 2035 [118].

Compare the application potential of these three CCS technologies in the context of the actual development in China. The application cost of CCS technology is high, with the cost of carbon capture technology accounting for 70-90\% of the total cost [119]. From a technical application point of view, the application of IGCC technology requires building a new power plant, which is more expensive than that of BECCS technology. For power generation efficiency and unit cost of decarbonization, IGCC technology is currently more 
advantageous. Combined with the index and the application target of CCS technology development (Table 5), IGCC technology currently has advantages and BECCS technology has more potential for application in the future.

Table 5. Comparison of different CCS technologies.

\begin{tabular}{|c|c|c|c|c|}
\hline \multicolumn{2}{|c|}{ Type of Technology } & $\begin{array}{c}\text { Integrated Gasification } \\
\text { Combined Cycle } \\
\text { (IGCC) }\end{array}$ & $\begin{array}{c}\text { Bioenergy with } \\
\text { Carbon Capture and } \\
\text { Storage (BECCS) } \\
\text { (Coal-Fired Power } \\
\text { Plant with } 90 \% \\
\text { Biomass Co-Firing) }\end{array}$ & $\begin{array}{l}\text { Direct Air Capture } \\
\text { (DAC) }\end{array}$ \\
\hline \multicolumn{2}{|c|}{ Power generation efficiency } & $\geq 40 \%$ [116] & $25 \%[84]$ & - \\
\hline \multicolumn{2}{|c|}{ Marginal cost of decarbonization $\left(\$ /\right.$ Ton $\left./ \mathrm{CO}_{2}\right)$} & 44 [120] & 68 [84] & $88-232[121,122]$ \\
\hline \multicolumn{2}{|c|}{$\begin{array}{l}\text { The most suitable area for } \mathrm{CO}_{2} \text { storage in } \\
\text { China [118] }\end{array}$} & \multicolumn{3}{|c|}{$\begin{array}{l}\text { Songliao Basin in Northeast China, Bohai Bay Basin in North China, Ordos } \\
\text { Basin in Central China, Tarim Basin, and Junggar Basin in West China }\end{array}$} \\
\hline \multirow{4}{*}{$\begin{array}{l}\text { Demand for emissions } \\
\text { reductions under } \\
\text { carbon-neutral target } \\
\text { (million tons/year) [118] }\end{array}$} & 2030 & 20 & 1 & 0 \\
\hline & 2040 & $200-500$ & $80-100$ & 15 \\
\hline & 2050 & $200-500$ & $200-500$ & $15-100$ \\
\hline & 2060 & $200-500$ & $300-600$ & $200-300$ \\
\hline \multicolumn{2}{|c|}{ Application evaluation } & $\begin{array}{l}\text { Need to build IGCC power } \\
\text { plants; high investment; } \\
\text { China is in the start-up } \\
\text { phase and requires large } \\
\text { subsidies [116] }\end{array}$ & $\begin{array}{l}\text { Need adequate } \\
\text { biomass fuel and test } \\
\text { the impact of the } \\
\text { operation on the soil }\end{array}$ & $\begin{array}{l}\text { Highly flexible and } \\
\text { advantageous for } \\
\text { capturing } \mathrm{CO}_{2} \\
\text { emissions from small } \\
\text { fuel units }\end{array}$ \\
\hline
\end{tabular}

\subsubsection{Policy and Publicity}

Government policy guidance and social publicity can promote low-carbon heating transformation. The Chinese government has issued several policies to promote low-carbon heating transformation. For subsidies of heating costs, the Notice on the Pilot Project of Central Financial Support for Clean Winter Heating in Northern Areas was issued in 2018, which provides different subsidies for three years depending on the administrative level of cities. For energy-saving consumption, the State Council issued the "13th FiveYear" Plan of Action for National Energy Conservation and increased various types of energy-saving consumption subsidies in 2017. For resource conservation, the Law of the People's Republic of China on Energy Conservation was revised and issued in 2018. For resource utilization, the National Energy Administration issued the Notice on Doing a Good Job of Renewable Energy Heating According to Local Conditions in 2021, indicating the development of the Chinese heating transformation toward diversification. For carbon trading, the National Carbon Emissions Trading Market was launched on 16 July 2021. Social promotion of low carbon heating was mainly carried out through television, the internet, and radio, specifically through international heating academic conferences and exchanges, the establishment of carbon neutrality research centers in various regions, lectures on low carbon transition development in universities, the establishment of energysaving development concepts in enterprises, and "coal to electricity" and "coal to gas" activities in streets and communities.

\subsection{The Optimal Path for Heating Decarbonization}

By comparing the utilization conditions and performance of different types of heat pumps, a more specific scheme was proposed based on the characteristics of Chinese urbanrural development and heating-related aspects. The carbon emissions of the technical schemes in urban and rural areas were calculated in this section as well. 


\subsubsection{Selection of Heat Pumps}

ASHP and GSHP are compared in four aspects: economic cost, heating efficiency and energy consumption, system operating conditions, and geographical environment of application. GSHP can be divided into soil source heat pump (SSHP) and water source heat pump (WSHP), and the latter can be divided into surface water source heat pump (SWHP) and ground water source heat pump (GWHP). ASHP extracts heat from the outdoor air to room for heating, and GSHP utilizes shallow geothermal energy as its heat source.

For economic costs, the economy of GSHP is better than that of ASHP [123]. The initial investment of SSHP (including equipment costs, installation costs, and civil construction costs) is usually 1.5 times higher than that of ASHP [47,124], but the costs of post maintenance are lower than those of ASHP. For service life, ASHP has a service life of 15-20 years, GSHP has a minimum of 20 years, and SSHP can reach 50 years.

For heating efficiency and energy consumption, the heating efficiency of SSHP is 3-5. WSHP is 4.5 [47]. ASHP is 2.5-3 [62]. The heating emissions of GSHP are lower than those of ASHP. The annual energy consumption of GSHP is $40 \%$ lower than that of ASHP, and the energy consumption of WSHP can be even lower than $40 \%$ or more $[62,125,126]$.

For system operating conditions, SSHP can be used in severe cold and cold regions. However, it is disruptive to the soil heat and cold balance, requiring the use of heat and cold balance equipment [127] or auxiliary heat source equipment underground pipes [50]. WSHP is susceptible to the environment [127], and the stability of GWHP is influenced by buildings. The heating efficiency of ASHP in low-temperature environments $\left(-20^{\circ} \mathrm{C}\right.$, or even $-5^{\circ} \mathrm{C}$ ) may lower the system heating efficiency to less than $2[37,63]$, making it difficult to meet the minimum standard of 1.8 for heating [128] and even leading to shut down [63]. In addition, ASHP systems may frost at $-12.8^{\circ} \mathrm{C}$ to $8{ }^{\circ} \mathrm{C}$ with humidity reaching above approximately $60 \%$ [129], which can damage the heat pump system. Although various defrosting techniques are available, further research is needed [130].

Regarding the application's geographical environment, the heat source of GSHP is shallow geothermal resources, which is abundantly distributed in various provinces, especially in the North China Plain and the middle and lower reaches of the Yangtze River Plain [131,132]. According to statistics, the total amount of shallow geothermal resources in 336 prefecture-level cities and above is equivalent to 9.5 billion tons of standard coal [133]. The Hebei Province in the north currently has the highest utilization rate, with a value of less than 3\% [50]. The application of ASHP requires the appropriate temperature and humidity. Two-thirds of the region in Northern China is below $-5{ }^{\circ} \mathrm{C}$ [134]. Areas with humidity higher than $60 \%$ are commonly found in Heilongiiang, Liaoning, Northern Jilin, Northern Inner Mongolia, and Northern Xinjiang $[129,135]$. Therefore, the application of ASHP is very limited. Many studies have shown the stability of the operation of ASHP in severe cold regions. However, their studies are limited to a couple of days and cannot indicate that the long-term stable operation can be achieved all winter [136,137].

Comparing the above factors, using GSHP and especially SSHP, developing shallow geothermal for heating has advantages over ASHP in China.

\subsubsection{Heating Technology Scheme}

We propose a heating scheme using GSHP in urban areas and PV-GSHP in rural residential areas of 15 provinces in Northern China and calculate the carbon emissions in 2030. According to the characteristics of Chinese urban-rural areas, centralized heating with GSHP was set in urban areas and distributed heating with PV-GSHP (a coupling system of PV to GSHP) systems was set in rural residential areas in the 15 provinces (Heilongjiang, Jilin, Liaoning, Neimenggu, Hebei, Beijing, Tianjin, Shanxi, Shandong, Henan, Gansu, Ningxia, Qinghai, Xinjiang, and Shaanxi) of Northern China. The land in 15 provinces is suitable for the installation of photovoltaic power generation devices and the power generated by PV can fully supply heat pump heating [59,138]. In rural areas, integrating $\mathrm{PV}$ generation into the grid for surplus power resale not only decreases rural heating costs but also increases electricity supply [33,139], and the feasibility of this scheme has been 
confirmed by researchers $[140,141]$, which is in line with national heating advocacy and the rural revitalization strategy [142,143]. When PV/T generation technology matures, it can bring a more efficient and economical way to heating systems.

\subsubsection{Carbon Emissions Accounting}

The carbon emissions calculation formula for heat hump heating is obtained from [144]. For Equation (1), $\mathrm{E}_{\mathrm{h}}$ is the energy consumption of electricity $(\mathrm{kWh}) ; \mathrm{b}$ is the heat load index $\left(\mathrm{w} / \mathrm{m}^{2}\right) ; \mathrm{t}$ is the heating time of each year $(\mathrm{h})$; $\mathrm{c}$ is the heat load coefficient; $\eta_{\mathrm{e}}$ is the COP of GSHP; and $A_{e}$ is the heating area $\left(\mathrm{m}^{2}\right)$. For Equation (2), $\mathrm{C}_{\mathrm{f}}$ is the comprehensive power emission factor $\left(\mathrm{g} \mathrm{CO}_{2} \mathrm{e} / \mathrm{kWh}\right) ; \beta_{\mathrm{i}}$ is the proportion of power generation from the ith energy in the total power generation (\%); and $\gamma_{i}$ is the carbon emission factor of the ith power generation form ( $\mathrm{g} \mathrm{CO}_{2} \mathrm{e} / \mathrm{kWh}$ ). For Equation (3), $\mathrm{Q}_{\mathrm{e}}$ is the carbon emissions (million tons) and $\rho$ is the line loss rate of transmission lines (\%):

$$
\begin{gathered}
\mathrm{E}_{\mathrm{h}}=(\mathrm{b} \times \mathrm{t} \times \mathrm{c} / 1000) / \eta_{\mathrm{e}} \times \mathrm{A}_{\mathrm{e}} ; \\
\mathrm{C}_{\mathrm{f}}=\sum_{\mathrm{i}=1}^{\mathrm{n}} \beta_{\mathrm{i}} \times \gamma_{\mathrm{i}} ; \\
\mathrm{Q}_{\mathrm{e}}=\frac{\mathrm{E}_{\mathrm{h}}}{(1-\rho)} \times \mathrm{C}_{\mathrm{f}} .
\end{gathered}
$$

For the heat load index b, based on the Design Code for City Heating Network (CJJ342010), this study sets urban buildings as energy-efficient buildings that meet the standard and the range of the heat load index $\mathrm{b}$ is $40-130 \mathrm{w} / \mathrm{m}^{2}$. Based on the Design Standard for Energy Efficiency of Rural Residential Buildings (GB/T50824-2013), Yao calculated the heat load index for rural houses in the northern region, which is $29.4-165.6 \mathrm{w} / \mathrm{m}^{2}$ [145]. However, only approximately $20 \%$ of buildings in rural areas of Northern China have adopted energy-saving measures in reality [22], and this percentage of buildings do not entirely meet building standards. The difference in heat load index between energy efficient and non-energy efficient buildings in rural areas is over $50 \%$ and even $60 \%$, which has been confirmed in many studies [146,147]. Therefore, this study sets the heat load index for rural non-energy-saving buildings at $58.8-331.2 \mathrm{w} / \mathrm{m}^{2}$ using $50 \%$ as the standard. Based on the target of general improvement of rural buildings in China in 2035, this study sets the heating energy consumption scenario in 2030 with $70 \%$ of energy savings (optimistic scenario) and $50 \%$ of energy savings (intermediate scenario) for rural buildings in 2030 [148].

For the heat load factor $\mathrm{c}$, it is often used in dynamic timesharing and zoning heating [149]. This study sets the heating as full, continuous heating and takes the value for possible intermittent heating as 1.1 [150].

For heating time $t$, considering the actual needs of 15 provinces, this study takes the value of 150 days [27].

For the COP of GSHP, the average COP of SSHP is 4.4 [65] and the average cop of WSHP is 4.5, so this study sets the COP of GSHP to 5 in 2030.

For the heating area $A_{e}$, the heating area of northern cities in China is $15.75 \times 10^{9} \mathrm{~m}^{2}$ in 2030 [144]. For rural heating areas, the rural population of the 15 northern heating provinces is $1.95 \times 10^{8}$ in 2030 [151], and the average number of rural households is 3.54 people in China in 2030 [152]. According to the average rural residential area of $80 \mathrm{~m}^{2}$ [27], the total rural residential heating areas of 15 provinces in Northern China in 2030 are $44.09 \times 10^{8} \mathrm{~m}^{2}$.

For the comprehensive power emission factor $C_{f}$, the power emission factor of clean power is lower than that of coal-fired power generation [12]. In Wang's study, the electric power structure based on the current growth rate of clean electricity is proposed, which can meet centralized heating with electric boilers in northern cities in 2030, in which the heating efficiency is $92.5 \%$ in 2030 , and the $\mathrm{C}_{\mathrm{f}}$ is $435.94 \mathrm{~g} \mathrm{CO}_{2} \mathrm{e} / \mathrm{kWh}$ [144]. That electric power structure can also meet the scenario set in this study in which the $\eta_{\mathrm{e}}$ of GSHP is 5 calculated by Equation (1), thus the $\mathrm{C}_{\mathrm{f}}$ of $435.94 \mathrm{~g} \mathrm{CO}_{2} \mathrm{e} / \mathrm{kWh}$ is also used as the urban 
heating in this study. The electricity supply in rural areas is set as PV generation, and $\mathrm{C}_{\mathrm{f}}$ is $85 \mathrm{~g} \mathrm{CO}_{2} \mathrm{e} / \mathrm{kWh}[153]$.

For the loss rate of transmission lines $\rho$, the line loss rate of PV generation in rural areas is 5\% [140]. As the proportion of clean energy power in the urban power structure increases, the line loss rate will also increase [154,155]. This study sets the line loss rate of the electric power structure of the city at $7 \%$ in 2030.

According to the carbon emissions accounting (Table 6), the total carbon emissions of heating in China in 2030 for the intermediate scenario and the optimistic scenario are 248-838 million tons and 246-827 million tons, respectively.

Table 6. Carbon emissions accounting.

\begin{tabular}{|c|c|c|}
\hline & Intermediate Scenario & Optimistic Scenario \\
\hline Scenario & $\begin{array}{c}50 \% \text { Energy Savings for Rural Residential } \\
\text { Areas and } 100 \% \text { Energy Savings for } \\
\text { Urban Buildings }\end{array}$ & $\begin{array}{c}70 \% \text { Energy Savings for Rural Residential } \\
\text { Areas and } 100 \% \text { Energy Savings for } \\
\text { Urban Buildings }\end{array}$ \\
\hline \multirow{2}{*}{$\begin{array}{l}\text { Carbon emissions of heating } Q_{e} \\
\text { (/million tons })\end{array}$} & $\begin{array}{l}\text { Rural areas: } 14-78 \\
\text { Urban areas: } 234-760\end{array}$ & $\begin{array}{l}\text { Rural areas: } 12-67 \\
\text { Urban areas: } 234-760\end{array}$ \\
\hline & Total: $248-838$ & Total: $246-827$ \\
\hline
\end{tabular}

\subsubsection{Parameter Analysis}

We provide a detailed analysis of the main parameters $C_{f}, b, t, c, A e$, and $\rho$ that have a large impact on the carbon emissions calculation results in this section.

"Cf" has a large impact on carbon emissions calculations. The carbon emissions of electrification of heating have a direct correlation with the electric power structure. According to Wang's study [144], thermal power has the highest carbon emission factor of $875.61 \mathrm{~g} \mathrm{CO}_{2} \mathrm{e} / \mathrm{kWh}$, while the values of clean power (hydropower, nuclear power, wind power, and solar power) range between 26 and $85 \mathrm{~g} \mathrm{CO}_{2} \mathrm{e} / \mathrm{kWh}$, indicating the importance of clean power for reducing carbon emissions. The electric power structure of this study for calculating carbon emissions is cited from Wang's study, which predicts an enhanced low carbon scenario at 2030 based on the current actual growth of various types of electricity in China: thermal power $(47.24 \%)$, hydropower $(1.41 \%)$, nuclear power $(0.64 \%)$, wind power $(35.18 \%)$, and solar power $(14.86 \%)$.

For the heat load index $b$ value, China's rapid urbanization has caused a huge gap in development between urban and rural areas. Although relevant standards define the heat load values for urban and rural buildings, in actual studies, factors such as backward building materials, low design standards, and backward energy-saving measures in rural areas greatly increase the unit energy consumption of buildings. Therefore, the actual rural heat load index is high [156]. Improving rural buildings is an important aspect of reducing carbon emissions from heating in the future.

The heating time $\mathrm{t}$ of 150 days in this study is based on the average heating time in 15 northern provinces and we set the daily heating time to $24 \mathrm{~h}$. We do not consider the reduction energy brought by the energy-saving technology of heating. AI heating technology is currently included in the 14th Five-Year Plan of each province in China. However, a large-scale application and study has not yet been formed. This study also considers possible intermittent heating, and takes the value c for 1.1.

With the development of urbanization in China, the heating area Ae in China's urban areas will become larger and the heating area Ae in rural areas will decrease. The direct factor related to the change is the urban and rural population change, which is calculated in this study precisely based on the urbanization rate in China.

China's power generation is currently dominated by coal-fired generation. The China Electricity Statistics Yearbook (2020-2021) shows that China's line loss rate $\rho$ has been within $10 \%$ for the last four decades and is decreasing year by year, to 5.6\% in 2020. Although clean electricity will increase the line loss rate to some extent, the line loss rate is $5 \%$ with 
PV, only according to existing studies. Considering that the electric power structure in 2030 is dominated by coal power generation, we set the line loss rate at $7 \%$ in cities.

\subsubsection{Comparison and Discussion}

By analyzing and comparing clean heating modes, using GSHP to develop shallow geothermal heating is the optimal choice for energy savings and emission reduction in China. Heating for heat pumps is widely advocated for application in developed countries and regions, such as the UK [157], Denmark [95], Switzerland [87], Germany [158], the EU [159], and California [70]. Some studies also advocate clean electricity together with the electrification of heating.

The significance of this study was confirmed by comparison and analysis with the following three studies.

Wang's study shows that the key factors for achieving electrification of heating in China are increasing renewable energy generation and improving heating efficiency, which correspond to decreasing $C_{f}$ and increasing $\eta_{e}$ in the accounting equation of this study, respectively [12].

Zhou's study [35], based on air quality, health benefits, and carbon reduction capacity, confirms the superiority of heat pump heating and shows that its emission reduction is closely related to clean electricity, which is consistent with this study. Zhou's study highlights that the promotion of heat pump heating tends to cause heating poverty in rural areas. It suggests policy recommendations to reduce rural heating costs, namely, improving both rural heating subsidies and building envelope efficiency. In the scenario design of using heat pumps for heating proposed in this study, the impact of these two factors on rural heating is considered together and carbon emissions are calculated to support the feasibility of the heating scheme.

From Ma's study [6], it can be found that the higher the urban heating emission reduction scenario, the higher the share that the electrification of heating occupies, which is consistent with the viewpoint of this study. Ma's study tends to use ASHP and this study chooses GSHP, which has a stronger heating potential. In rural heating, Ma proposed heating by biomass boilers, while boilers for heating convert high-grade energy into low-grade heat for heating, which causes a large amount of wasted resources. It is known from our study that the efficiency of renewable energy for heating through power generation is higher than that of other modes. The heating method of PV-HP proposed in this study can achieve clean heating and clean power, and perhaps some revenue. For carbon emissions, the $\mathrm{CO}_{2}$ emissions in Ma's study are at least 400 million tons under the target of global warming control at $2{ }^{\circ} \mathrm{C}$, which is higher than the minimum emission limit of 246 million tons for the scenario set in this study, thus the heating scenario in this study has some superiority.

Regarding whether the amount of shallow geothermal resources in China can meet the heating needs set in this study, it has been shown that the total amount of shallow geothermal resources in 15 northern provinces is $30.99 \times 10^{12} \mathrm{kWh} / \mathrm{a}$, based on the planned area of the central cities of prefecture-level cities in China in 2012 [160]. The amount of resources that meet the heating needs of geothermal resources in 15 provinces in 2030 set in this study is $(3.16-12.4) \times 10^{12} \mathrm{kWh}$. The utilization potential of shallow geothermal resources is related to the floor area coefficient and geothermal recoverable coefficient and is also limited by the construction cost and difficulty [132]. In addition, the heat loss rate using shallow geothermal resources is usually up to $50 \%$. Therefore, rational planning of building heating areas and improving geothermal extraction technology can effectively improve the heating utilization of shallow geothermal resources.

\section{Conclusions and Recommendations}

This study systematically analyzes the heating transformation progress of coal to gas and coal to electricity in China, compares and evaluates the current common clean heating modes at home and abroad, and analyzes the industrial and building sectors, 
CCS technologies, policies, and publicity related to low carbon heating. On this basis, we propose a low-carbon heating scheme, where GSHP and PV-GSHP need to be utilized in urban areas and in rural areas, respectively. China's low-carbon heating path has not yet been formed and different regions have different advantages in using different heating modes. By evaluating these heating modes from multiple perspectives, the development of shallow geothermal heat using GSHP has the greatest advantages. Cleaner industrial production is expected to promote low-carbon heating in China. Building improvements, especially in rural buildings, can bring further emission reductions to China's heating. At present, various CCS technologies have not been applied on a large scale due to cost and technical factors and this change is expected to be achieved after 2030. Combining these heating technology potentials and the current state of development in China's urban and rural areas, we propose a suitable heating technology scheme and determine its superiority by calculating the carbon emissions of the scheme.

Currently, air source heat pumps are widely used in China for two reasons: First, according to the plan (2017-2021), the transformation time in pilot cities is limited to only five years. The simplicity of air source heat pump installation can meet the time requirements. Second, the heating subsidy mechanism determined by the administrative level is inflexible, and there is a shortage of funds for regional transformation, thus ASHP with a lower initial cost is preferred.

Therefore, the implementation of the heating technology scheme requires a gradual transformation plan and a flexible heating subsidy policy. For example, the subsidy policy should be formulated with reference to the resource endowment conditions and economic development of the region.

Using heat pumps to develop shallow geothermal resources is a feasible heating scheme. However, specific implementation still requires several supporting aspects to cooperate.

Therefore, several suggestions are presented:

1. The carbon emissions of electrification of heating are related to the structure of electricity, thus low-carbon heating and clean electricity should be considered in an integrated manner.

2. In areas rich in biomass resources, coal-fired power plants can opt for selecting the transformation development method of co-firing with biomass. Furthermore, lowcarbon development can be achieved with CCS technology in the future, which indirectly promotes heat hump heating.

3. Design requirements for shallow geothermal resources should be added to building standards.

4. Improvement should be made to the survey level of shallow geothermal and the application technology of GSHP. It is also necessary to issue relevant guidelines.

5. For rural areas, the implementation of PV-GSHP projects should be considered in the context of urbanization development. The energy-saving transformation of rural buildings should be promoted early according to the energy-saving standard (GB55015-2021).

The heating technology scheme is based on the perspective of optimizing the utilization of heating resources. Considering the utilization of industrial waste heat, $\mathrm{CHP}$, and CCS technologies, carbon emissions may be further reduced. The carbon emissions calculation is based on the total shallow geothermal resources in 15 provinces and does not consider specific calculation at the provincial level. The distribution of geothermal resources at the provincial level may be uneven and the difficulty of development may be different. The scenario set is focused on the potential for the energy-saving development of rural residential buildings and more possible scenarios, especially the specific implementation costs, which will be considered in the next step.

Overall, this study provides a reference for the mode selection and technical scheme of low carbon heating in China, especially in the utilization of heat pumps and the deployment of urban and rural heating schemes. This study also provides a reference scheme for China's heating industry for the efforts of carbon peak and carbon neutrality, however, other regions or countries with a similar situation could also take reference. 
Author Contributions: Conceptualization, S.Z. and J.Z.; methodology, S.Z. and J.Z.; validation, S.Z., J.Z. and X.H.; formal analysis, S.Z., J.Z. and X.H.; data curation, S.Z., J.Z. and X.H.; writing-original draft preparation, X.H., S.Z. and J.Z.; writing—review and editing, S.Z., J.Z. and X.H.; supervision, S.Z. and J.Z. All authors have read and agreed to the published version of the manuscript.

Funding: This research was funded by the Second Tibetan Plateau Scientific Expedition and Research Program (STEP), grant no. 2019QZKK1003, the Strategic Priority Research Program of the Chinese Academy of Sciences, grant no. XDA19040102, and the National Natural Science Foundation of China, grant no. 42071281.

Informed Consent Statement: Not applicable.

Data Availability Statement: Not applicable.

Acknowledgments: We thank Ayman Elshkaki from the Institute of Geographic Sciences and Natural Resources Research, CAS, for providing us with the many constructive suggestions to improve the manuscript.

Conflicts of Interest: The authors declare no conflict of interest.

\section{References}

1. $\quad$ Li, B.G.; Gasser, T.; Ciais, P.; Piao, S.L.; Tao, S.; Balkanski, Y.; Hauglustaine, D.; Boisier, J.-P.; Chen, Z.; Huang, M.; et al. The contribution of China's emissions to global climate forcing. Nature 2016, 531, 357-361. [CrossRef] [PubMed]

2. Wang, H.K.; Lu, X.; Deng, Y.; Sun, Y.G.; Nielsen, C.P.; Liu, Y.; Zhu, G.; Bu, M.L.; Bi, J.; McElroy, M.B. China's CO2 peak before 2030 implied from characteristics and growth of cities. Nat. Sustain. 2019, 2, 748-754. [CrossRef]

3. Government of the People's Republic of China. Announcement for "13th Five-Year" National Strategic Emerging Industry Development Plan. Available online: http:/ / www.gov.cn/zhengce/content/2016-12/19/content_5150090.htm (accessed on 30 December 2021).

4. Wang, J.D.; Zhou, Z.G.; Zhao, J.N.; Zheng, J.F.; Guan, Z.Q. Towards a cleaner domestic heating sector in China: Current situations, implementation strategies, and supporting measures. Appl. Therm. Eng. 2019, 152, 515-531. [CrossRef]

5. Ashfaq, A.; Ianakiev, A. Cost-minimised design of a highly renewable heating network for fossil-free future. Energy 2018, 152, 613-626. [CrossRef]

6. Ma, S.N.; Guo, S.Y.; Zheng, D.Q.; Chang, S.Y.; Zhang, X.L. Roadmap towards clean and low carbon heating to 2035: A provincial analysis in Northern China. Energy 2021, 225, 120164. [CrossRef]

7. Chen, S.Y.; Chi, H. Analysis of the environmental effects of the clean heating policy in Northern China. Sustainability 2021, 13, 6695. [CrossRef]

8. Liu, Q.; Liang, X.Y.; Wang, H.; Hong, Q.Q. Current situation and trend analysis of clean heating in North China. Energy China 2021, 43, 17-22.

9. Lin, B.Q.; Jia, Z.J. Economic, energy and environmental impact of coal-to-electricity policy in China: A dynamic recursive CGE study. Sci. Total Environ. 2020, 698, 134241. [CrossRef]

10. Yan, Z.H. Effects Estimation and Path Choice of "Coal to Electricity" and "Coal to Gas" in Beijing-Tianjin-Hebei Region. Master's Thesis, Dongbei University of Finance and Economics, Dalian, China, 2019.

11. Zhao, N.; Zhang, Y.X.; Li, B.W.; Hao, J.; Chen, D.Y.; Zhou, Y.G.; Dong, R.J. Natural gas and electricity: Two perspective technologies of substituting coal-burning stoves for rural heating and cooking in Hebei province of China. Energy Sci. Eng. 2019, 7, 120-131. [CrossRef]

12. Wang, J.X.; Zhong, H.W.; Yang, Z.F.; Wang, M.; Kammen, D.M.; Liu, Z.; Ma, Z.M.; Xia, Q.; Kang, C.Q. Exploring the trade-offs between electric heating policy and carbon mitigation in China. Nat. Commun. 2020, 11, 6054. [CrossRef]

13. Vaishnav, P.; Fatimah, A.M. The environmental consequences of electrifying space heating. Environ. Sci. Technol. 2020, 54, 9814-9823. [CrossRef]

14. Liu, Z.; Chen, X.L.; Cai, J.Y.; Balezentis, T.; Li, Y. The impact of "coal to gas" policy on air quality: Evidence from Beijing, China. Energies 2020, 13, 3876. [CrossRef]

15. Zhao, S.; Hu, B.; Gao, W.; Li, L.; Huang, W.; Wang, L.; Yang, Y.; Liu, J.; Li, J.; Ji, D.; et al. Effect of the "coal to gas" project on atmospheric $\mathrm{NO}_{X}$ during the heating period at a suburban site between Beijing and Tianjin. Atmos. Res. 2020, $241,104977$. [CrossRef]

16. Liu, H.; Mauzerall, D.L. Costs of clean heating in China: Evidence from rural households in the Beijing-Tianjin-Hebei region. Energy Econ. 2020, 90, 104844. [CrossRef]

17. Weng, Z.X.; Han, E.; Wu, Y.F.; Shi, L.; Ma, Z.; Liu, T.T. Environmental and economic impacts of transitioning to cleaner heating in Northern China. Resour. Conserv. Recycl. 2021, 172, 105673. [CrossRef]

18. Xu, S.; Ge, J.P. Sustainable shifting from coal to gas in North China: An analysis of resident satisfaction. Energy Policy 2020, 138, 111296. [CrossRef] 
19. Zhu, L.; Liao, H.; Hou, B.D.; Cheng, L.; Li, H. The status of household heating in Northern China: A field survey in towns and villages. Environ. Sci. Pollut. Res. 2020, 27, 16145-16158. [CrossRef]

20. Sheikh, I.; Callaway, D. Decarbonizing space and water heating in temperate climates: The case for electrification. Atmosphere 2019, 10, 435. [CrossRef]

21. Lund, R.; Persson, U. Mapping of potential heat sources for heat pumps for district heating in Denmark. Energy 2016, 110, 129-138. [CrossRef]

22. Zhang, Z.; Zhou, Y.; Zhao, N.; Li, H.; Tohniyaz, B.; Mperejekumana, P.; Hong, Q.; Wu, R.; Li, G.; Sultan, M.; et al. Clean heating during winter season in Northern China: A review. Renew. Sustain. Energy Rev. 2021, 149, 111339. [CrossRef]

23. Feng, T.; Du, H.B.; Coffman, D.M.; Qu, A.Y.; Dong, Z.F. Clean heating and heating poverty: A perspective based on cost-benefit analysis. Energy Policy 2021, 152, 112205. [CrossRef]

24. Slorach, P.C.; Stamford, L. Net zero in the heating sector: Technological options and environmental sustainability from now to 2050. Energy Convers. Manag. 2021, 230, 113838. [CrossRef]

25. Popovski, E.; Fleiter, T.; Santos, H.; Leal, V.; Fernandes, E.O. Technical and economic feasibility of sustainable heating and cooling supply options in southern European municipalities-A case study for Matosinhos, Portugal. Energy 2018, 153, 311-323. [CrossRef]

26. Fajardy, M.; Morris, J.; Gurgel, A.; Herzog, H.; Mac Dowell, N.; Paltsev, S. The economics of bioenergy with carbon capture and storage (BECCS) deployment in a $1.5^{\circ} \mathrm{C}$ or $2{ }^{\circ} \mathrm{C}$ world. Glob. Environ. Change 2021, 68, 102262. [CrossRef]

27. Zheng, W.; Zhang, Y.C.; Xia, J.J.; Jiang, Y. Cleaner heating in Northern China: Potentials and regional balances. Resour. Conserv. Recycl. 2020, 160, 104897. [CrossRef]

28. Su, C.; Dalgren, J.; Palm, B. High-resolution mapping of the clean heat sources for district heating in Stockholm City. Energy Convers. Manag. 2021, 235, 113983. [CrossRef]

29. Liu, J.L.; Li, D.Y. Analysis on Development Status and Problems of "Coal to Gas". In Proceedings of the Workshop on Construction and Efficient Operation of Heating Engineering, Hangzhou, China, 17-19 April 2018.

30. Jin, W. Introduction of heating forms in southern China. China Constr. Met. Struct. 2014, 1, 40-45.

31. Wu, Q.; Tu, K.; Xu, S.H.; Zeng, Y.F.; Liu, S.Q.; Zhu, K. Discuss on the optimization of precise allocation of energy supply and consumption in China. Energy China 2020, 42, 7-10.

32. Long, W.D.; Liang, H. Discussion on paths of carbon peak and carbon neutrality of urban buildings in China. Heat. Vent. Air Cond. 2021, 51, 1-17.

33. Liu, X.H.; Han, J.A.; Zhang, N.; Wang, J.J. Status of decentralized civil heating technology in China. Bull. Chin. Acad. Sci. 2019, 34, 401-408.

34. Zhang, S.D.; Xuan, J.Y.; Song, H.; Zhang, Y.; Jin, C.R.; Yan, D.Z. Research on Benefit and Optimum Development of Residents Heating Projects Based on Different Ways. In Proceedings of the International Conference of Green Buildings and Environmental Management, Qingdao, China, 15-17 June 2018.

35. Zhou, M.; Liu, H.X.; Peng, L.Q.; Qin, Y.; Chen, D.; Zhang, L.; Mauzerall, D.L. Environmental benefits and household costs of clean heating options in Northern China. Nat. Sustain. 2021, 2021, 1-10. [CrossRef]

36. Zhou, W.Q.; Wu, H.C.; Li, P.; Zhang, Z.J.; Wang, M.S.; Kang, X. Comparative study on environmental benefits of different clean heating modes in Northern China based on testing. Environ. Pollut. Control. 2021, 43, 416-420.

37. Zhao, W.Y.; Deng, G.F.; Guan, Y.L.; Yu, C.Y.; Tang, F.; Jiang, S.H. Cost and environmental benefit analysis of clean heating technologies in Northern rural area. Pet. Plan. Eng. 2020, 31, 41-44.

38. Li, Z.Y.; Xu, Z.W.; Sun, Y.Y.; Wang, Z.C.; Deng, S.M.; Cui, Y.M.; Xu, W.; Wang, W. A Review on Coal-to-Electricity Policies into Practice in Northern China. In Proceedings of the IOP Conference Series: Earth and Environmental Science, Cardiff, UK, 24-25 September 2019.

39. Wang, Q.; Zheng, S.L. Impact of joint prevention and control action on atmospheric pollutant concentration in $2+26$ cities. China Popul. Resour. Environ. 2019, 29, 51-62.

40. Zhang, W.; Lawell, C.Y.C.L.; Umanskaya, V.I. The effects of license plate-based driving restrictions on air quality: Theory and empirical evidence. J. Environ. Econ. Manag. 2017, 82, 181-220. [CrossRef]

41. Duan, X.L.; Jiang, Y.; Wang, B.B.; Zhao, X.G.; Shen, G.F.; Cao, S.Z.; Huang, N.; Qian, Y.; Chen, Y.T.; Wang, L. Household fuel use for cooking and heating in China: Results from the first Chinese Environmental Exposure-Related Human Activity Patterns Survey (CEERHAPS). Appl. Energy 2014, 136, 692-703. [CrossRef]

42. Chen, H.; Chen, W.Y. Potential impact of shifting coal to gas and electricity for building sectors in 28 major Northern cities of China. Appl. Energy 2019, 236, 1049-1061. [CrossRef]

43. Buker, M.S.; Riffat, S.B. Solar assisted heat pump systems for low temperature water heating applications: A systematic review. Renew. Sustain. Energy Rev. 2016, 55, 399-413. [CrossRef]

44. Nastasi, B.; LoBasso, G. Power-to-Gas integration in the transition towards future urban energy systems. Int. J. Hydrogen Energy 2017, 42, 23933-23951. [CrossRef]

45. Gluyas, J.G.; Adams, C.A.; Busby, J.P.; Craig, J.; Hirst, C.; Manning, D.A.C.; McCay, A.; Narayan, N.S.; Robinson, H.L.; Watson, S.M.; et al. Keeping warm: A review of deep geothermal potential of the UK. Proc. Inst. Mech. Eng. Part A J. Power Energy 2018, 232, 115-126. [CrossRef] 
46. Pelda, J.; Stelter, F.; Holler, S. Potential of integrating industrial waste heat and solar thermal energy into district heating networks in Germany. Energy 2020, 203, 117812. [CrossRef]

47. Gaur, A.S.; Fitiwi, D.Z.; Curtis, J. Heat pumps and our low-carbon future: A comprehensive review. Energy Res. Soc. Sci. 2021, 71, 101764. [CrossRef]

48. Tissen, C.; Menberg, K.; Benz, S.A.; Bayer, P.; Steiner, C.; Gotzl, G.; Blum, P. Identifying key locations for shallow geothermal use in Vienna. Renew. Energy 2021, 167, 1-19. [CrossRef]

49. Chen, Y.K.; Jensen, I.G.; Kirkerud, J.G.; Bolkesjo, T.F. Impact of fossil-free decentralized heating on northern European renewable energy deployment and the power system. Energy 2021, 219, 119576. [CrossRef]

50. Song, C.F.; Li, Y.; Taha, R.; Ma, L.; Zhao, J.; Li, W.J. Application and development of ground source heat pump technology in China. Prot. Control. Mod. Power Syst. 2021, 6, 1-18. [CrossRef]

51. Liang, C.Z. Key areas and policy suggestions for promoting clean heating in Northern China. Constr. Sci. Technol. 2017, 18, 9-14.

52. Connor, P.M.; Xie, L.; Lowes, R.; Britton, J.; Richardson, T. The development of renewable heating policy in the United Kingdom. Renew. Energy 2015, 75, 733-744. [CrossRef]

53. Frank, L.; Jacob, K.; Quitzow, R. Transforming or tinkering at the margins? Assessing policy strategies for heating decarbonisation in Germany and the United Kingdom. Energy Res. Soc. Sci. 2020, 67, 101513. [CrossRef]

54. Leurent, M.; Jasserand, F.; Locatelli, G.; Palm, J.; Rama, M.; Trianni, A. Driving forces and obstacles to nuclear cogeneration in Europe: Lessons learnt from Finland. Energy Policy 2017, 107, 138-150. [CrossRef]

55. Li, J.F. Current situation and prospect of biomass energy development in China. China Power Enterp. Manag. 2021, 1, 70-73.

56. Han, Z.W.; Wang, Y.R.; Yang, J.; Meng, X.; Pang, Y.S. Status quo and prospect of heat pump heating and air conditioning system in severe cold areas. Build. Sci. 2013, 29, 124-133.

57. Wang, Q. Heating, Cooling and Economy Analysis of Solar-Ground Coupled Heat Pump System in Cold Regions. Master's Thesis, Harbin Institute of Technology, Harbin, China, 2012.

58. Cheng, J.K.; Zuo, Y.; Xu, B.; Tang, J. Feasibility analysis of PVT technology application in Qinghai area. Electron. World 2019, 23, 117-118.

59. Wang, Z.; Yang, L.; Hu, J.; Gu, Z. Analysis on cascade heat utilization of solar energy in building heating based on phase change thermal storage. Procedia Eng. 2017, 205, 2266-2272. [CrossRef]

60. Zhao, B.; Lu, D.W.; Liu, W.A.; Wang, P.; Gao, F. Technology and application of solar central heating in extremely cold and high-altitude areas. Huadian Technol. 2020, 42, 51-55.

61. Melaina, M.W.; Antonia, O.; Penev, M. Blending Hydrogen into Natural Gas Pipeline Networks: A Review of Key Issues; National Renewable Energy Laboratory: Golden, CO, USA, 2013; pp. 1-131.

62. Zhang, J.G. Prospects for heat pump heating technology under the goal of "carbon neutrality". Energy China 2021, 43, 12-18.

63. Shi, Y.; Hu, E.S.; Zhen, B. Analysis of operation characteristics of air source heat pump in Northeast severe cold areas. J. Jilin Jianzhu Univ. 2020, 37, 33-38.

64. Wang, K.H.; Dong, C.J.; Li, B.Y. The feasible analysis of ground-coupled heat pump by using the solar energy as assisted source. Energy Conserv. 2006, 25, 33-35.

65. Wang, J.H.; Yao, H.Q.; Zhao, S.W.; Zhang, W.K. Application and development of combined system of ground sourceand solar heat pumps. Dist. Heat. 2021, 2, 85-93.

66. Aguilar, F.J.; Aledo, S.; Quiles, P.V. Experimental study of the solar photovoltaic contribution for the domestic hot water production with heat pumps in dwellings. Appl. Therm. Eng. 2016, 101, 379-389. [CrossRef]

67. Wang, Y.; Weng, Z.X.; Zhang, M.; Ma, Z.; Zhao, Z.M. Policy research on promoting the development of biomass in China under the background of clean heating. Environ. Prot. 2020, 48, 60-63.

68. Shen, Y. The Spatial Distribution of Solar Energy and the Comprehensive Potential Evaluation of Regional Exploitation and Utilization in China. Master's Thesis, Lanzhou University, Lanzhou, China, 2014.

69. Babacan, O.; Causmaecker, S.D.; Gambhir, A.; Fajardy, M.; Rutherford, A.W.; Fantuzzi, A.; Nelson, J. Assessing the feasibility of carbon dioxide mitigation options in terms of energy usage. Nat. Energy 2020, 5, 720-728. [CrossRef]

70. California Council on Science and Technology. California's Energy Future-The View to 2050. Available online: https:// escholarship.org/uc/item/2tb1c1mv\#main (accessed on 21 November 2021).

71. Kosmadakis, G. Estimating the potential of industrial (high-temperature) heat pumps for exploiting waste heat in EU industries. Appl. Therm. Eng. 2019, 156, 287-298. [CrossRef]

72. Thiel, G.P.; Stark, A.K. To decarbonize industry, we must decarbonize heat. Joule 2021, 5, 531-550. [CrossRef]

73. Shi, J.; Chen, W.; Yin, X. Modelling building's decarbonization with application of China TIMES model. Appl. Energy 2016, 162, 1303-1312. [CrossRef]

74. Amoruso, G.; Donevska, N.; Skomedal, G. German and Norwegian policy approach to residential buildings' energy efficiency-a comparative assessment. Energy Effic. 2018, 11, 1375-1395. [CrossRef]

75. Leibowicz, B.D.; Lanham, C.M.; Brozynski, M.T.; Vazquez-Canteli, J.R.; Castejon, N.C.; Nagy, Z. Optimal decarbonization pathways for urban residential building energy services. Appl. Energy 2018, 230, 1311-1325. [CrossRef]

76. Broad, O.; Hawker, G.; Dodds, P.E. Decarbonising the UK residential sector: The dependence of national abatement on flexible and local views of the future. Energy Policy 2020, 140, 111321. [CrossRef] 
77. Hamburg, A.; Kuusk, K.; Mikola, A.; Kalamees, T. Realisation of energy performance targets of an old apartment building renovated to nZEB. Energy 2020, 194, 116874. [CrossRef]

78. Mac Uidhir, T.; Rogan, F.; Collins, M.; Curtis, J.; Gallachoir, B.P.O. Improving energy savings from a residential retrofit policy: A new model to inform better retrofit decisions. Energy Build. 2020, 209, 109656. [CrossRef]

79. Zabnienska, A.; Khordehgah, N.; Jouhara, H. Annual performance analysis of the PV/T system for the heat demand of a low-energy single-family building. Renew. Energy 2021, 163, 1923-1931. [CrossRef]

80. Bui, M.; Adjiman, C.S.; Bardow, A.; Anthony, E.J.; Boston, A.; Brown, S.; Fennell, P.S.; Fuss, S.; Galindo, A.; Hackett, L.A.; et al. Carbon capture and storage (CCS): The way forward. Energy Environ. Sci. 2018, 11, 1062-1176. [CrossRef]

81. Sifat, N.S.; Haseli, Y. A critical review of $\mathrm{CO}_{2}$ capture technologies and prospects for clean power generation. Energies 2019, 12, 4143. [CrossRef]

82. Muhammad, H.A.; Sultan, H.; Lee, B.; Imran, M.; Baek, I.H.; Baik, Y.J.; Nam, S.C. Energy minimization of carbon capture and storage by means of a novel process configuration. Energy Convers. Manag. 2020, 215, 112871. [CrossRef]

83. Brandl, P.; Bui, M.; Hallett, J.P.; Dowell, N.M. Beyond 90\% capture: Possible, but at what cost? Int. J. Greenh. Gas Control. 2021, 105, 103239. [CrossRef]

84. Xing, X.F.; Wang, R.; Bauer, N.; Ciais, P.; Cao, J.J.; Chen, J.M.; Tang, X.; Wang, L.; Yang, X.; Boucher, O.; et al. Spatially explicit analysis identifies significant potential for bioenergy with carbon capture and storage in China. Nat. Commun. 2021, 12, 3159. [CrossRef]

85. Buchele, R.; Kranzl, L.; Hummel, M. What is the impact of the policy framework on the future of district heating in Eastern European countries? The case of Brasov. Energy Strategy Rev. 2018, 19, 72-75. [CrossRef]

86. Knobloch, F.; Pollitt, H.; Chewpreecha, U.; Daioglou, V.; Mercure, J.F. Simulating the deep decarbonisation of residential heating for limiting global warming to $1.5^{\circ} \mathrm{C}$. Energy Effic. 2019, 12, 521-550. [CrossRef]

87. Narula, K.; Chambers, J.; Streicher, K.N.; Patel, M.K. Strategies for decarbonising the Swiss heating system. Energy 2019, 169, 1119-1131. [CrossRef]

88. Schwarz, M.; Knoeri, C. Accelerating the Diffusion of Energy-Efficient Building Technologies with Policies-The Case of Switzerland. In Proceedings of the Climate Resilient Cities-Energy Efficiency \& Renewables in the Digital Era, Lausanne, Switzerland, 4-6 September 2019.

89. Herbes, C.; Rilling, B.; Ringel, M. Policy frameworks and voluntary markets for biomethane-How do different policies influence providers' product strategies? Energy Policy 2021, 153, 112292. [CrossRef]

90. Sovacool, B.K.; Demski, C.; Noel, L. Beyond climate, culture and comfort in European preferences for low-carbon heat. Glob. Environ. Change Hum. Policy Dimens. 2021, 66, 102200. [CrossRef]

91. B.E.C.R.C.o.T. University. China Building Energy Efficiency Development Report 2019; China Building Industry Press: Beijing, China, 2019; pp. 1-153.

92. C.H.I.C.o.C.B.E.C. Association. Simple Report on the Development of Clean Heating Industry in China (2020); China Economic Press: Beijing, China, 2020; pp. 1-18.

93. Jiang, Y. Report on the Development of Heating Industry in China in 2020. Available online: https://www.hvactt.com/article/16 5-173-1239.html (accessed on 21 December 2021).

94. Xiong, W.M.; Wang, Y.; Mathiesen, B.V.; Lund, H.; Zhang, X.L. Heat roadmap China: New heat strategy to reduce energy consumption towards 2030. Energy 2015, 81, 274-285. [CrossRef]

95. Buhler, F.; Zuhlsdorf, B.; Nguyen, T.V.; Elmegaard, B. A comparative assessment of electrification strategies for industrial sites: Case of milk powder production. Appl. Energy 2019, 250, 1383-1401. [CrossRef]

96. Jiang, X.M.; Xiong, W.H.; Wang, J.F.; Su, N. Analysis on potential and utilization of low-grade industrial waste heat resources in Beijing-Tianjin-Hebei and its surrounding areas. Energy China 2017, 39, 32-36.

97. Qiao, J.; Shang, J.C.; Tao, L.; Sang, H.X.; Ge, Y.H. Study on integrated utilization of waste heat in industrial park. Resour. Econ. Environ. Prot. 2017, 1, 12-19.

98. Kiani, B.; Hamamoto, Y.; Akisawa, A.; Kashiwagi, T. $\mathrm{CO}_{2}$ mitigating effects by waste heat utilization from industry sector to metropolitan areas. Energy 2004, 29, 2061-2075. [CrossRef]

99. Manz, P.; Kermeli, K.; Persson, U.; Neuwirth, M.; Fleiter, T.; Crijns-Graus, W. Decarbonizing district heating in EU-27 + UK: How much excess heat is available from industrial sites? Sustainability 2021, 13, 1439. [CrossRef]

100. Demir, H.; Mobedi, M.; Ülkü, S. A review on adsorption heat pump: Problems and solutions. Renew. Sustain. Energy Rev. 2008, 12, 2381-2403. [CrossRef]

101. Yao, C.N.; Liang, J.Q. Practice exploration and action of carbon peak in China's construction sector. Constr. Sci. Technol. 2021, $11,8-13$.

102. Liu, Y.; Zhen, P.Q. Development direction of building energy saving materials under the background of carbon neutrality. China Build. Mater. 2021, 5, 144-147.

103. Kong, F.W.; Zhang, Q.Q.; Li, H.B. Problems and countermeasures in the development of green buildings. J. Shenyang Jianzhu Univ. Soc. Sci. 2021, 23, 258-262.

104. Dai, W.Q. Application of thermal insulation materials in building exterior wall thermal insulation. Constr. Mater. Decor. 2020, $603,44-45$.

105. Fang, J. Characteristics and application progress of green building energy saving materials. Anhui Archit. 2020, 10, 101-102. 
106. He, X.K.; Qian, Y.T.; Zhou, S.F.; Wang, X.; Zhang, S.Y. Current situation analysis and standardization research of building external wall thermal insulation and energy-saving materials in China. Qual. Explor. 2020, 17, 22-29.

107. Xu, W.; Sun, D.Y.; Lu, F.; Yu, Z.Y.; Wang, J. Research progress and reflection on the definition and technical index system of nearly zero-energy building. Build. Sci. 2018, 34,1-9.

108. Wang, B.T. Application of frequency control technology in heating system. Plant Maint. Eng. 2021, 1, 158-159.

109. Li, J.X.; Li, G. Application analysis of frequency converter in electric automation control of central heating. Equip. Technol. 2020, $176,1-4$.

110. Gao, H.R.; Wu, Z.M. Current status and technical analysis of heating system renovation in existing residential areas. Dist. Heat. 2021, 1, 8-15.

111. Meng, L.S. Application of frequency conversion technology in heating system. Theor. Res. Urban Constr. 2015, 5, 1494-1495.

112. Zhao, Z.Q.; Zhang, H.; Jiang, C.; Wang, Q.F.; Lin, X.L. Review on global CCUS technology and application. Mod. Chem. Ind. 2021, $41,5-10$.

113. Dahowski, R.T.; Davidson, C.L.; Li, X.C.; Wei, N. A $\$ 70 / \mathrm{tCO}_{2}$ greenhouse gas mitigation backstop for China's industrial and electric power sectors: Insights from a comprehensive CCS cost curve. Int. J. Greenh. Gas Control 2012, 11, 73-85. [CrossRef]

114. Jin, H.G.; Anthony, W.; Annika, S.; Li, G.; Ashok, B. Roadmap for Carbon Capture and Storage Demonstration and Deployment in the People's Republic of China; Asian Development Bank Press: Mandaluyongbu, Philippines, 2015; pp. 1-68.

115. Fan, Q.; Xu, S.S.; Liu, Y.; Liu, K.; Chen, X.; Luo, L.Z.; Dong, S.L.; Tao, J.Y.; Chen, Z.; Cheng, J.; et al. Application and demonstration of IGCC-based pre-combustion $\mathrm{CO}_{2}$ capture technology. Electr. Power 2017, 50, 163-167.

116. Lu, X.; Cao, L.; Wang, H.K.; Peng, W.; Xing, J.; Wang, S.X.; Cai, S.Y.; Shen, B.; Yang, Q.; Nielsen, C.P.; et al. Gasification of coal and biomass as a net carbon-negative power source for environment-friendly electricity generation in China. Proc. Natl. Acad. Sci. USA 2019, 116, 842-849. [CrossRef] [PubMed]

117. Zhang, J.; Guo, W.; Zhang, B.; Zhang, R.J.; Yang, B.L.; Wu, Z.Q. Research progress on direct capture of $\mathrm{CO}_{2}$ from air. Clean Coal Technol. 2021, 27, 57-68.

118. Cai, B.F.; Li, Q.; Zhang, X. Ministry of Ecology and Environment: Annual Report on Carbon Dioxide Capture, Utilization and Storage (CCUS) in China in 2021. Available online: http:/ / www.199it.com/archives/1288692.html (accessed on 15 December 2021).

119. Zhao, T. Research on Technology Diffusion of Carbon Capture and Storage (CCS) in China's Thermal Power Enterprises. Master's Thesis, North China Electric Power University, Baoding, China, 2019.

120. Reng, Y.Q.; Chen, D.F.; Xu, S.S.; Li, X.Y.; Tao, J.Y.; Liu, G. Study on typical domestic and foreign IGCC technology applications. Electr. Power 2019, 52, 7-13.

121. Keith, D.W.; Holmes, G.; Angelo, D.S.; Heidel, K. A process for capturing $\mathrm{CO}_{2}$ from the atmosphere. Joule 2018, 2, 1572-1594. [CrossRef]

122. Azarabadi, H.; Lackner, K.S. A sorbent-focused techno-economic analysis of direct air capture. Appl. Energy 2019, 250, 959-975. [CrossRef]

123. Yin, M.G. Feasible research of ground water heat pump system in Luoyang. Refrig. Air Cond. 2010, 24, 52-55.

124. Murray, P.; Marquant, J.; Niffeler, M.; Mavromatidis, G.; Orehounig, K. Optimal transformation strategies for buildings, neighbourhoods and districts to reach $\mathrm{CO}_{2}$ emission reduction targets. Energy Build. 2020, 207, 109569. [CrossRef]

125. Marinelli, S.; Lolli, F.; Gamberini, R.; Rimini, B. Life Cycle Thinking (LCT) applied to residential heat pump systems: A critical review. Energy Build. 2019, 185, 210-223. [CrossRef]

126. Greening, B.; Azapagic, A. Domestic heat pumps: Life cycle environmental impacts and potential implications for the UK. Energy 2012, 39, 205-217. [CrossRef]

127. Xu, Y.S.; Wang, X.W.; Shen, S.L.; Zhou, A.N. Distribution characteristics and utilization of shallow geothermal energy in China. Energy Build. 2020, 229, 110479. [CrossRef]

128. Zhao, M. Application of ultra low temperature air source heat pump in frigid area. Inn. Mong. Petrochem. Ind. 2020, 46, 24-26.

129. Wu, Y.; Liu, X.; Liang, C.Z.; Huang, K.L.; Li, H. Development status and key technical indicators of low temperature air source heat pump. Constr. Sci. Technol. 2019, 10, 20-27.

130. Zhang, Q.L.; Zhang, L.; Nie, J.Z.; Li, Y.L. Techno-economic analysis of air source heat pump applied for space heating in Northern China. Appl. Energy 2017, 207, 533-542. [CrossRef]

131. Hou, J.C.; Cao, M.C.; Liu, P.K. Development and utilization of geothermal energy in China: Current practices and future strategies. Renew. Energy 2018, 125, 401-412. [CrossRef]

132. Wang, G.L.; Liu, Y.G.; Zhu, X.; Zhang, W. The status and development trend of geothermal resources in China. Earth Sci. Front. 2020, 27, 1-9.

133. Wang, Y.; Liu, Y.; Dou, J.; Li, M.; Zeng, M. Geothermal energy in China: Status, challenges, and policy recommendations. Util. Policy 2020, 64, 101020. [CrossRef]

134. Su, C.; Madani, H.; Palm, B. Heating solutions for residential buildings in China: Current status and future outlook. Energy Convers. Manag. 2018, 177, 493-510. [CrossRef]

135. Fang, Z.Q.; Wang, Z.Q.; Wei, J.; Suzuki, H.; Ogawa, T.; Xu, X.G. Analysis of frosting characteristics of air source heat pumps in winter based on actual operation Data. J. Refrig. 2020, 41, 71-77.

136. Xu, J.; Li, H.Q.; Wang, D.Y.; Wang, J.R.; Deng, Z.; Xie, P. Influence of ambient temperature on heating performance of air source heat pump. Refrig. Air Cond. 2019, 19, 84-88. 
137. Zhang, Y.N.; Ma, Q.; Li, B.X.; Fan, X.M.; Fu, Z.B. Application of an air source heat pump (ASHP) for heating in Harbin, the coldest provincial capital of China. Energy Build. 2017, 138, 96-103. [CrossRef]

138. Qiu, T.Z.; Wang, L.C.; Lu, Y.B.; Zhang, M.; Qin, W.M.; Wang, S.Q.; Wang, L.Z. Potential assessment of photovoltaic power generation in China. Renew. Sustain. Energy Rev. 2022, 154, 111900. [CrossRef]

139. Ke, G.H.; Zhang, X.; Liu, L.Z.; Zhang, T. Feasibility of comprehensive utilization of energy in rural household heating in Beijing. Energy Res. Manag. 2020, 1, 98-102.

140. Yin, L.L. Study on Integrated Design of Rural Green Residential Photovoltaic Architecture in Northeast China. Master's Thesis, Jilin Jianzhu University, Jilin, China, 2020.

141. Peng, S.N.; Guo, J.X.; Ma, X.F. Combined heating system of photovoltaic-air source heat pump for independent rural houses in the North. J. Qingdao Univ. Technol. 2019, 40, 103-109.

142. National Development and Reform Commission. Notice on Accelerating the Development and Utilization of Shallow Geothermal Energy and Promoting the Replacement of Coal Burning in Northern Heating Region (NO. 2278). Available online: https: / / www.ndrc.gov.cn/fggz/hjyzy/jnhnx/201801/t20180108_1134157.html?code=\&state=123 (accessed on 1 December 2021).

143. National Energy Administration. "Photovoltaic + Heating" System will be Applied. Available online: http://www.nea.gov.cn/ 2018-05/14/C_137178049.htm (accessed on 5 December 2021).

144. Wang, W.J.; Li, F. Study on substitutable value of electric heating instead of coal heating in Northern China under carbon constraints. J. Clean. Prod. 2020, 260, 121155. [CrossRef]

145. Chen, Y.; Wang, Z.W.; Wei, P. Climatic zoning for the building thermal design in China's rural areas. Build. Serv. Eng. Res. Technol. 2021, 42, 1-15. [CrossRef]

146. Yang, M. Sustainable Roadmap and Key Technology Development on "Zero-Coal, Low Energy" Rural Housing in Northern China. Ph.D. Thesis, Tsinghua University, Beijing, China, 2011.

147. Zhang, S.S.; Dong, C.C.; Wang, L.T. Calculation and analysis of heating heat load index of rural residential buildings in China. Low Temp. Archit. Technol. 2009, 31, 97-99.

148. Government of the People's Republic of China. Notice on the Pilot Project of Rural Housing Construction. Available online: http:/ / www.gov.cn/xinwen/2019-02/04/content_5363829.htm (accessed on 3 December 2021).

149. Wu, Y.Q. Heating of the Time-Sharing Partition Building Thermal Load Calculation and Palisade Structure Optimization. Master's Thesis, Xi'an University of Architecture and Technology, Xi'an, China, 2015.

150. Ministry of Housing and Urban-Rural Development of the People's Republic of China. Technical Regulations for Radiant Heating and Cooling [with Article Description] JGJ142-2012. Available online: http:/ /www.jianbiaoku.com/webarbs/book/124/1048594 shtml (accessed on 2 December 2021).

151. Sun, D.; Zhou, L.; Li, Y.; Liu, H.; Shen, X.; Wang, Z.; Wang, X. New-type urbanization in China: Predicted trends and investment demand for 2015-2030. J. Geogr. Sci. 2017, 27, 943-966. [CrossRef]

152. Guo, S.Y.; Yan, D.; Hu, S.; Zhang, Y. Modelling building energy consumption in China under different future scenarios. Energy 2021, 214, 119063. [CrossRef]

153. A Review of Estimates of Carbon Emissions from Coal, Gas, Nuclear, Hydro and Other Power Plants in the Whole Life Cycle by Different Institutions. Available online: https://news.bjx.com.cn/html/20171225/869765.shtml (accessed on 1 December 2021).

154. Zhang, J.; Liu, S.C.; Ma, Y.F.; Xiao, M.; Zhang, G.H.; Liu, S.P.; Zhou, W.Y.; Zhao, S.C.; Wang, X.B. Analysis on the influence of the new energy generation on the line loss of the main power grid under typical operation mode. Qinghai Electr. Power 2019, $38,19-22$.

155. Zhang, F.D. An Analysis of the Impact of Large Scale Wind Power on Power System Line Loss. Master's Thesis, Yanshan University, Qinhuangdao, China, 2013.

156. Evans, M.; Yu, S.; Song, B.; Deng, Q.Q.; Liu, J.; Delgado, A. Building energy efficiency in rural China. Energy Policy 2014, 64, 243-251. [CrossRef]

157. Lowes, R.; Woodman, B.; Speirs, J. Heating in Great Britain: An incumbent discourse coalition resists an electrifying future. Environ. Innov. Soc. Transit. 2020, 37, 1-17. [CrossRef]

158. Bartholdsen, H.K.; Eidens, A.; Loffler, K.; Seehaus, F.; Wejda, F.; Burandt, T.; Oei, P.Y.; Kemfert, C.; Hirschhausen, C. Pathways for Germany's low-carbon energy transformation towards 2050. Energies 2019, 12, 2988. [CrossRef]

159. Connolly, D.; Lund, H.; Mathiesen, B.V.; Werner, S.; Möller, B.; Persson, U.; Boermans, T.; Trier, D.; Østergaard, P.A.; Nielsen, S. Heat roadmap Europe: Combining district heating with heat savings to decarbonise the EU energy system. Energy Policy 2014, 65, 475-489. [CrossRef]

160. Lin, W.J.; Liu, Z.M.; Wang, W.L.; Wang, G.L. The assessment of geothermal resources potential of China. Geol. China 2013, $40,312-321$ 